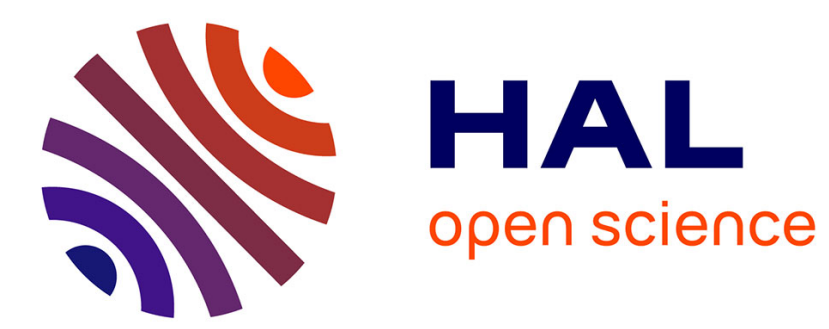

\title{
Agricultural price instability: a survey of competing explanations and remedies
}

Christophe C. Gouel

\section{To cite this version:}

Christophe C. Gouel. Agricultural price instability: a survey of competing explanations and remedies. Journal of Economic Surveys, 2012, 26 (1), pp.129-156. 10.1111/j.1467-6419.2010.00634.x . hal01001218

\section{HAL Id: hal-01001218 \\ https://hal.science/hal-01001218}

Submitted on 15 Nov 2016

HAL is a multi-disciplinary open access archive for the deposit and dissemination of scientific research documents, whether they are published or not. The documents may come from teaching and research institutions in France or abroad, or from public or private research centers.
L'archive ouverte pluridisciplinaire HAL, est destinée au dépôt et à la diffusion de documents scientifiques de niveau recherche, publiés ou non, émanant des établissements d'enseignement et de recherche français ou étrangers, des laboratoires publics ou privés. 


\title{
Agricultural Price Instability: A Survey of Competing Explanations and Remedies*
}

\author{
Christophe Gouel ${ }^{\dagger}$
}

\begin{abstract}
There are two explanations for agricultural price dynamics. One follows cobweb logic and models fluctuations driven by expectation errors but emphasises that these expectations create complex dynamics and possibly chaos. The other stems from the rational expectations tradition of dynamics driven by real shocks. The empirical evidence tends to support the latter, but is not conclusive. The rational expectations model generates an optimal dynamic path from which no improvement can be expected from public intervention. However, if we take account of all the potential market failures in agricultural markets, and especially in developing countries, this conclusion might require some qualifications, although an appropriate policy design for stability has still to be achieved. This paper surveys the positive and normative literature on agricultural prices, highlighting empirical evidence and identifying remaining unresolved issues.
\end{abstract}

Keywords: cobweb model, market dynamics, price expectations, price stabilisation.

JEL classification: D84, Q11, Q18.

${ }^{*}$ This is the peer reviewed version of the following article: "Gouel, C. (2012). Agricultural price instability: A survey of competing explanations and remedies. Journal of Economic Surveys, 26(1), 129-156.", which has been published in final form at DOI: 10.1111/j.1467-6419.2010.00634.x. This article may be used for non-commercial purposes in accordance with Wiley Terms and Conditions for Self-Archiving.

The author is grateful to Jean-Marc Bourgeon, Benjamin Carton, Sébastien Jean, and an anonymous referee for helpful comments and suggestions. Support from the AgFoodTrade project funded under the 7th Framework Programme for Research and Development, DG-Research, European Commission, is acknowledged.

${ }^{\dagger}$ INRA, CEPII and Ecole Polytechnique (christophe.gouel@inra.grignon.fr) 


\section{Introduction}

Boom and bust events tend to characterise agricultural markets. In the food crises of 1973-1974 and 2007-2008, the prices of several agricultural commodities more than doubled in the course of a few months, before an even more rapid decline to lower levels (see Figure 1). Such episodes inevitably trigger concerns about the peculiarities of agriculture and the need of public intervention in such essential markets. Public involvement in stabilisation of food prices has been commonplace for a very long time. According to the Bible, Joseph stored grain during seven years of abundance to face seven years of famine (Genesis 41-47). In early modern Europe, grain market regulation was widespread and deregulation started only in the nineteenth century with the greater integration of national and international markets (Persson, 1999). Until recently, international agreements have been aimed at reducing the price volatility of several commodities (Gilbert, 1996).

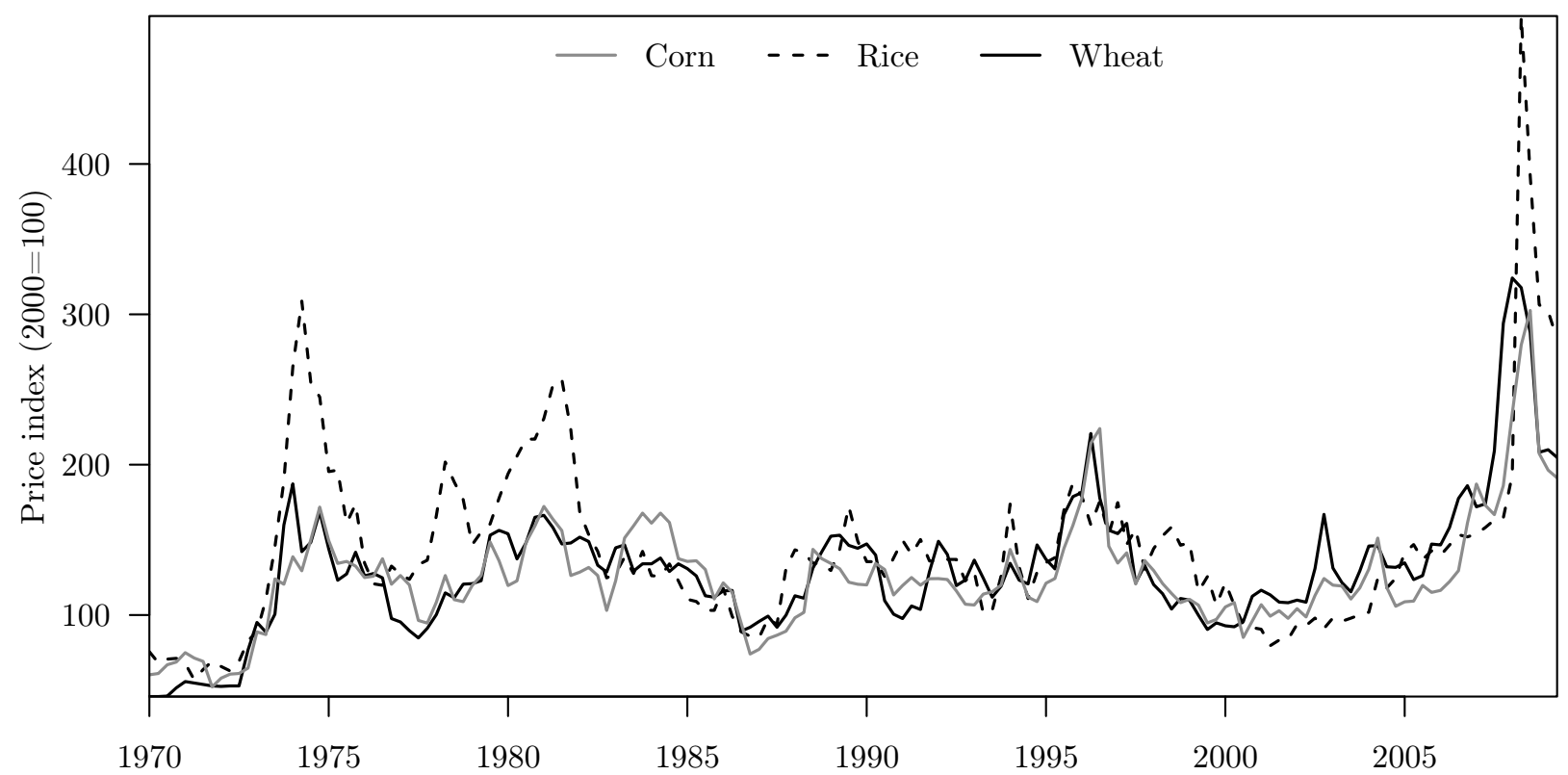

Figure 1. Quarterly nominal prices of key cereals since 1970. Source: IMF, International Financial Statistics.

With rising incomes, the share of staple foods in families' budgets has become so low that sheltering consumers in developed countries from price instability has become of less concern than protecting producers. Many developed country agricultural policies are now aimed explicitly at stabilisation of producer prices and incomes.

This paper offers a review of some of the current explanations of agricultural price dynamics, and discusses the way that governments should intervene in markets. Since this paper makes the link between the dynamics and public intervention, it focuses on theoretical justifications for price dynamics: it does not examine empirical explanations, such as those provided by time-series models (surveyed in Labys, 2006). It concentrates on issues of annual fluctuations, which allows to abstract 
from the effect of short-run financial speculation.

Historically, two explanations have been proposed for the price dynamics in the agricultural sector. First, that prices are driven by real shocks, an explanation that fits perfectly with the rational expectations framework. Second, that price dynamics stem from forecasting errors, which is based on the coordination issue created by price instability. ${ }^{1}$ These two explanations lead to opposite policy conclusions. If real shocks affect supply, price adjustment is a natural correction process. Policy makers could want to mitigate their adverse effects on fragile populations, but they should not alter the overall dynamics. If price volatility is caused by a failure to forecast next period market conditions, future scarcity is not driving resource allocation and the state of the economy could be improved through public intervention. Of course, these two explanations are not mutually exclusive. The literature has, however, rarely mixed them. So, in order to clarify the properties of each theory, the opposition is maintained in the paper.

This paper focuses on models related to annual crops not perennial crops or breeding. Volatility is not less an issue for these sectors. The explanations of their instability also present the opposition between endogenously and exogenously driven dynamics. However, the dynamically complex production processes involved in perennial crops and breeding would introduce additional complexities to the models. ${ }^{2}$ In a sense, the production process of annual crops could also be made complex by considering models featuring technology relying on capital investments with costly adjustments. For the sake of simplicity, these issues of investments are not treated here.

\section{The linear cobweb and its critiques}

Ezekiel (1938) proposes one of the first formalisations of agricultural price dynamics with his famous cobweb theorem. ${ }^{3}$ This model describes a salient feature of agricultural markets: that the productive decision is made before its realisation, leading to a short-run inelastic supply. When this is accompanied by a low elastic demand the implication is that any market disturbance will have sizeable effects on price. Since adjustment can come only from a very rigid demand, prices need to change considerably to induce significant change in demand. This model is the basis for all current approaches to this problem and is presented in full in Table 1. Demand (1) and supply (2) curves are linear. Supply is subject to additive white noise disturbance $\epsilon_{t}$. At each period, producers plan future output on the basis of the current price (4).

The deterministic part of the dynamics depends on the demand and supply slopes. Starting from an equilibrium that is different from the deterministic steady state, the sequence of equilibrium prices

\footnotetext{
${ }^{1}$ As real events show (Headey and Fan, 2008), a complete characterisation of agricultural prices should also include the effects of macroeconomic shocks or oil price fluctuations. This paper does not discuss these factors, but models focused on production, price and storage adjustments, such as those examined below, can be extended to include these drivers.

${ }^{2}$ See, e.g., Rosen et al. (1994) and Aadland (2004) for models of cattle cycles, and French and Matthews (1971) for perennial crops.

${ }^{3}$ Waugh (1964) discusses earlier contributions to this model.
} 
Table 1. The simple linear cobweb model

\begin{aligned} \hline$q_{t}^{D} & =a-b p_{t} & &$ Demand \\ $q_{t}^{S} & =c+d \hat{p}_{t}+\epsilon_{t} & &$ Supply \\ $q_{t}^{D} & =q_{t}^{S} & &$ Market equilibrium \\ $\hat{p}_{t} & =p_{t-1} & &$ Naive expectations \end{aligned}

can display three different behaviours, depending on the relative demand and supply slopes. When $d / b<1$, prices converge with dampened oscillations, to the steady state price $p^{e}=(a-c) /(b+d)$. Oscillations are explosive if $d / b>1$, and steady if $d / b=1$.

This model suffers from serious internal contradictions, which are set out in Buchanan (1939). Diverging and oscillatory regimes with systematic forecasting errors involve greater losses than profits for producers. An economically consistent model would require explicit assumptions about the entry of more producers willing to waste money on an unprofitable business.

The most common critiques concern explosive dynamics, which implies diverging and negative prices. That the supply curve is more elastic than demand seems natural in agricultural markets, which would make the explosive regime the norm. Consequently, some authors tried to extend the stability range. Hooton (1950) and Akerman (1957) propose that supply is probably not so inelastic in the short term. In times of affluence, speculators stock grain surpluses, which they can sell later at higher prices. Stockpiling behaviour will tend to make demand (supply) more elastic for low (high) prices, thus stabilising the market. Akerman (1957) notes that farmers will probably not follow immediately a sudden change in prices, and will adjust their production schedules but with a delay. Nerlove (1958) formalises this idea by proposing adaptive expectations; producers revise their expectations depending on their last period forecasting errors,

$$
\hat{p}_{t}=(1-w) \hat{p}_{t-1}+w p_{t-1} .
$$

This scheme encompasses the naive case for $w=1$. Because producers react less to price change, this scheme extends the stability range. Prices converge to equilibrium when $d / b<2 / w-1$.

Even after extending the stability of the cobweb model, it remains that the main dynamic behaviour derives from systematic forecasting errors occurring in a rather simple model. Muth (1961) uses the cobweb model as an illustration of the interests of rational expectations. These systematic errors imply that producers are wasting scarce information. He advocates that expectations should be consistent with economic theory, which means that agents should base their decisions on the information available at the time:

$$
\hat{p}_{t}=\mathrm{E}_{t-1}\left(p_{t}\right) .
$$

Under rational expectations, the dynamics of the previous system collapses to random fluctuations 
around the steady state $p^{e}$,

$$
p_{t}=p^{e}-\frac{\epsilon_{t}}{b}
$$

The rational expectations critique has not completely eliminated the cobweb model from the economist's toolbox. It took some time for rational expectations to become a standard economic assumption, and use of the linear cobweb model, at least in its Nerlovian setting, has remained popular in applied works especially for identifying short and long-run price elasticities (see Sadoulet and de Janvry, 1995, Ch. 4).

\section{Nonlinear dynamics models}

Twenty years ago, the article "cobweb theorem" from the New Palgrave Dictionary of Economics noted a decreasing interest in cobweb models (Pashigian, 1987). However, the situation has reverted. The simplicity of the cobweb model makes it a useful framework for studying market stability and the role of expectations; it is widely used for modelling demand for education, in the learning literature and the nonlinear dynamics literature. The cobweb model widely spreads out from agricultural economics to become an alternative matrix to rational expectations, for time lag decisions. One of the developments relevant to agricultural markets is the extension of the linear cobweb model to nonlinear dynamics.

The dynamics in a simple linear cobweb are limited to explosive, convergence to steady state and two-period cycles. ${ }^{4}$ However, the introduction of nonlinear features, such as nonlinear curves, heterogeneous agent or risk aversion, generates complex dynamics and can lead to chaos. These additions respond in part to the criticisms of the traditional cobweb models.

Nonlinear dynamics is about systems characterised by nonlinear time evolution equations. It has important consequences for dynamic behaviour. In linear models, small changes in parameters lead to small changes in behaviour. For instance, we can consider how the dynamics changes in the linear cobweb when the parameter $b$, which governs demand elasticity, is changed. Starting from the diverging oscillations regime, when demand elasticity increases, the oscillations diverge more and more slowly until demand elasticity is sufficient to achieve a two-period regime. An additional increase in demand elasticity changes the behaviour to converging oscillations, beginning with a very slow convergence, close to regular oscillation. In nonlinear systems, however, a change in parameters can induce dramatic behavioural changes. Qualitative change to model behaviour caused by a parameter variation is referred to as bifurcation. Nonlinear models can produce chaotic dynamics. Extreme sensitivity to initial conditions is characteristic of chaos, which implies that we cannot forecast what will happen in the future based on the current conditions, because of our inability to observe without error these conditions. We know only that the time path is bounded (Zhang, 2006).

\footnotetext{
${ }^{4}$ There are an infinity of two-period cycles. When demand slope equal supply slope, every couple of prices that are symmetric with respect to the steady state price constitutes a cycle.
} 


\subsection{Nonlinear cobweb models}

In a cobweb model, with naive expectations, if the supply and demand curves are monotonic, the behaviour is qualitatively the same as in the linear case. Only three types of behaviour will occur: convergence to a fixed point; two-period cycles; and divergence. Artstein (1983) and Jensen and Urban (1984) represent a departure from this case with the introduction of non-monotonic curves. This simple change introduces the possibility of chaotic dynamics. The assumption of non-monotonicity in demand or supply curves, however, is quite strong and is not adopted in other studies. For example, Chiarella (1988) and Hommes (1991, 1994) show that simple S-shaped monotonic supply curves and adaptive expectations are sufficient to generate nonlinear deterministic dynamics. Table 2 provides a representation of their model, which is illustrated in Figure 2. This is similar to Nerlove's model apart from its S-shaped supply curve $\left(2^{\prime}\right)$. It also abstracts from stochastic shocks. In trying to emphasise the endogenous nature of fluctuations, these studies focus only on deterministic dynamics: no disturbance to supply is included.

Table 2. Cobweb model with monotonic S-shaped supply curve

\begin{tabular}{|c|c|c|}
\hline$q_{t}^{D}=a-b p_{t}$ & Demand & (1) \\
\hline$q_{t}^{S}=\arctan \left(\lambda \hat{p}_{t}\right)$ & Supply & $\left(2^{\prime}\right)$ \\
\hline$q_{t}^{D}=q_{t}^{S}$ & Market equilibrium & \\
\hline$\hat{p}_{t}=(1-w) \hat{p}_{t-1}+w p_{t-1}$ & Adaptive expectations & $\left(4^{\prime}\right)$ \\
\hline
\end{tabular}

What is interesting about this model, and contrasts with the linear case, is the unstable case. The range of stability is still defined for $q^{S^{\prime}}\left(p^{e}\right) / q^{D^{\prime}}\left(p^{e}\right)<2 / w-1$ (value close to 0.29 in Figure 2a). Beyond this, prices are bounded and follow either stable or chaotic oscillations. As Nerlove (1958) shows, adaptive expectations tend to increase the range of stability, but in this setting the effects are more complex. As expected, the amplitude of the fluctuations decreases when the weighting factor for expectations, $w$, decreases from 1 (naive expectations) to 0 , but the nature of the dynamics changes, shifting from two-period oscillations to a convergence to the steady state, after passing through chaos. Thus, the range of fluctuations decreases, but paradoxically prices become unpredictable. Figure 2b illustrates this extreme sensitivity to initial conditions created by chaos. Starting from two very close price expectations, trajectories are distinct after a few periods.

Other nonlinear features are explored in the literature. Boussard (1996) introduces risk-aversion in the linear cobweb model using a mean-variance framework. The variance introduces a quadratic term on prices potentially leading to chaos. Onozaki et al. (2000) generate chaotic dynamics by introducing adjustment costs in a cobweb model.

Nonlinear cobweb models respond to several of the criticisms of the simple linear cobweb model. They introduce a more realistic dynamics than the three regimes in the linear case. However, Buchanan's (1939) critique that such models often risk of representing sectors that are likely to go bankrupt is not addressed seriously. This is confirmed by Commendatore and Currie (2008), who 


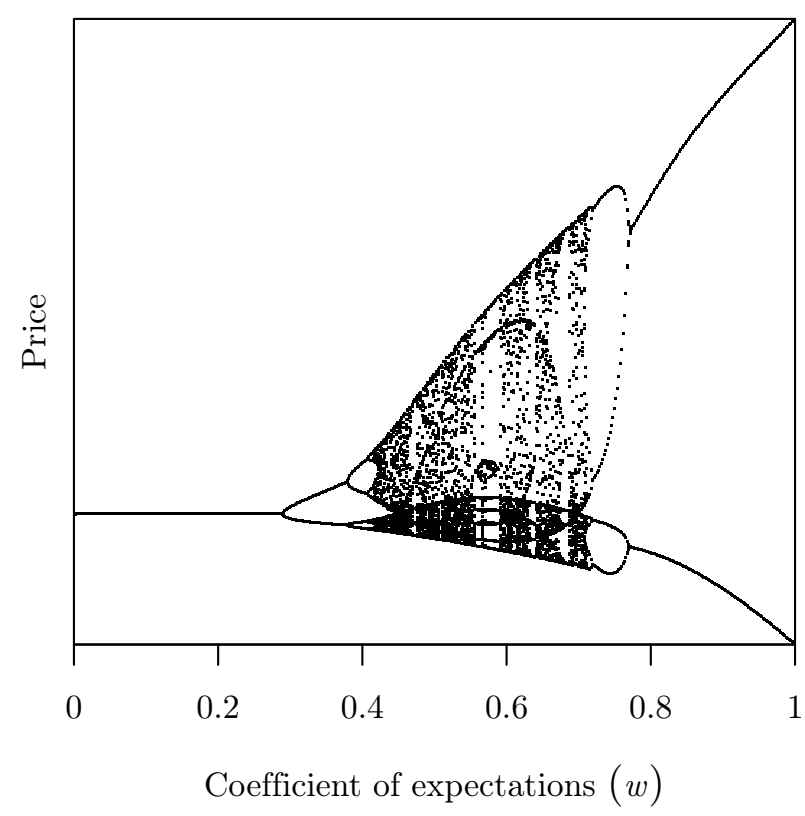

(a) Bifurcation diagram

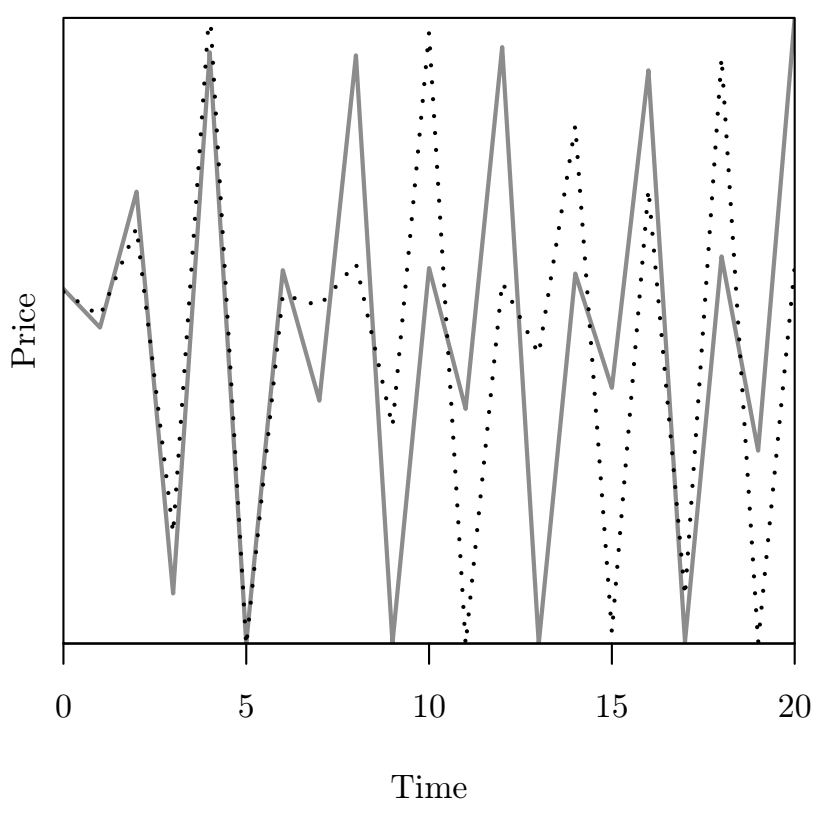

(b) Two chaotic trajectories

Figure 2. Behaviour of the nonlinear cobweb with S-shaped supply curve. Parameters: $a=1$, $b=0.25, \lambda=4$. In the bifurcation diagram (a), for $w$ close to 0 there is a stable equilibrium; increasing $w$ to 0.29 produces a bifurcation to stable two-period oscillations; after several more bifurcations there are chaotic oscillations, then further increasing $w$ close to 1 produces a return to stable oscillations. For the two chaotic trajectories $(w=0.7)$, initial points are very close, with the initial expected prices equal to 0.3 (dotted line) and 0.31 (solid line), but, after a few iterations, the trajectories are completely different.

demonstrate that neglecting borrowing constraints in a nonlinear cobweb model results in financial crisis. Introducing borrowing constraints limits too risky commitments. As most nonlinear cobweb models lack this financial aspect, they are subject to the same limitation and are not internally consistent.

\subsection{Heterogenous agent models}

With bounded rationality à la Baumol and Quandt (1964), rule-of-thumb expectations can be rationalised as a trade-off between costly rational expectations and cheap backward looking expectations. This logic is formalised in a seminal paper by Brock and Hommes (1997). If building good expectations is costly, and agents make rational choices between different expectation schemes based on their past performance, a complex dynamics emerges. In times of limited instability, rational expectations are too costly to be used widely and agents switch to naive expectations, which tends to destabilise the market. Stability returns when a sufficient share of agents switches back to rational expectations. This scheme, developed by Brock and Hommes (1997), justifies backward-looking expectations as a rational trade-off between good but costly, and bad but cheap expectations. 
This model (Table 3) is built from simple elements of the linear cobweb with linear demand (1) and supply (6) functions. Supply is the sum of the contributions of agents with naive and rational expectations (7). The share of each agent in the population, $n_{h t}$, evolves through a discrete choice model (11) based on last period profits (10), with $h$ indexing the type of agent. ${ }^{5} \beta$ is intensity of choice, with naive expectations supposed to be freely available $\left(C_{2}=0\right)$, and rational expectations costly $\left(C_{1}=C\right)$. The interaction between the two types of agents leads to doldrums followed by booms and busts (see Figure 3b top panel). When prices are stable, rational expectations are not worth their cost, thus, most agents switch to naive expectations, which are destabilising. In periods of market exuberance, naive expectations give rise to costly forecasting errors, and the share of rational expectations agents rises rapidly until the market stabilises (Figure 3b bottom panel). This dynamic behaviour is extremely sensitive to the intensity of choice (Figure 3a). For small values, agents tend to stay with their expectations schemes and prices converge to a steady state. Complex behaviours emerge when the intensity of choice increases.

Table 3. Cobweb model with heterogeneous expectations

\begin{tabular}{rlrl}
\hline$q_{t}^{D}$ & $=a-b p_{t}$ & & Demand \\
$q_{h t}^{S}$ & $=d \hat{p}_{h t}$ & & Supply by agent type \\
$q_{t}^{S}$ & $=\sum_{h=1}^{2} n_{h t} q_{h t}^{S}$ & & Total supply \\
$q_{t}^{D}$ & $=q_{t}^{S}$ & & $(6)$ \\
$\hat{p}_{1 t}$ & $=p_{t}$ & & Market equilibrium \\
$\hat{p}_{2 t}$ & $=p_{t-1}$ & & Rational expectations agents \\
$\Pi_{h t}$ & $=q_{h t}^{S} p_{h t}-\left(q_{h t}^{S}\right)^{2} / 2 d-C_{h}$ & & Naive expectations agents \\
$n_{h t}$ & $=\frac{\exp \left(\beta \Pi_{h, t-1}\right)}{\sum_{j=1}^{2} \exp \left(\beta \Pi_{j, t-1}\right)}$ & & Profit \\
\end{tabular}

This literature responds to Buchanan's (1939) critique of survival producers with irrational expectations, who should be driven out of the market by producers with rational expectations. Backwardlooking expectations become a viable strategy when expectations are costly and dynamics complex. There are various extensions of this model. ${ }^{6}$ Brock and Hommes (1998) apply the framework to an asset pricing model. Goeree and Hommes (2000) and Lasselle et al. (2005) generalise Brock and Hommes's (1997) model by introducing nonlinear demand and supply curves, and adaptive expectations.

Backward-looking expectations are criticised because they generate systematic errors with a strong cyclic pattern. Under chaotic dynamics, we would expect rule-of-thumb expectations to have better

\footnotetext{
${ }^{5}$ This model is a simplified version of Brock and Hommes model. It considers that the fitness measure collapses to last period profits without taking into account more distant profits. It does not change the main conclusions of the model.

${ }^{6}$ See Hommes (2006) for a survey of the heterogeneous agent models literature.
} 


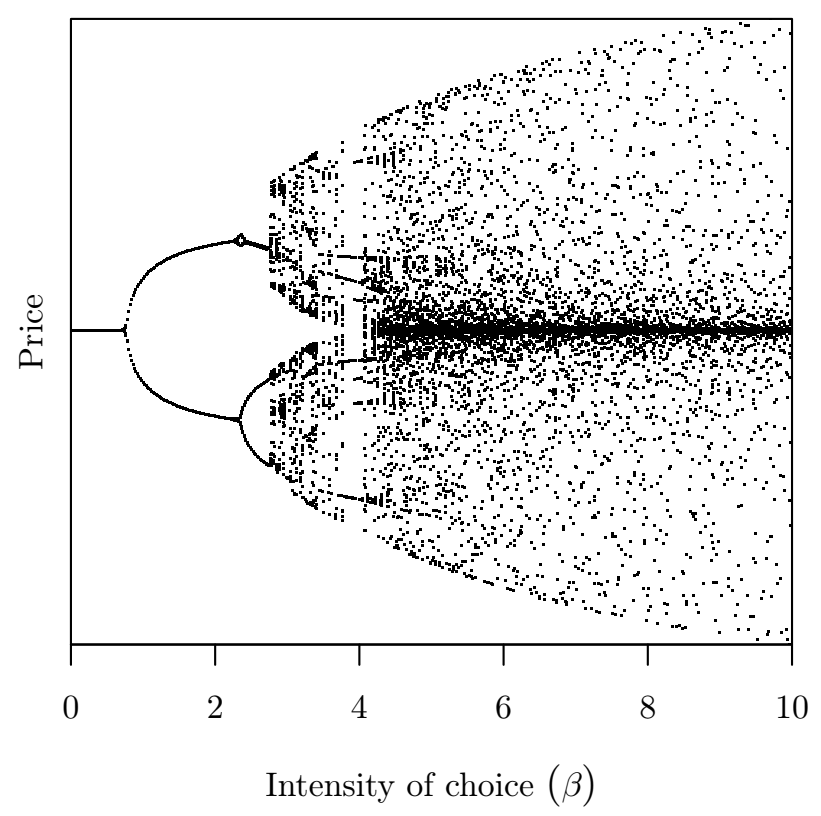

(a) Bifurcation diagram

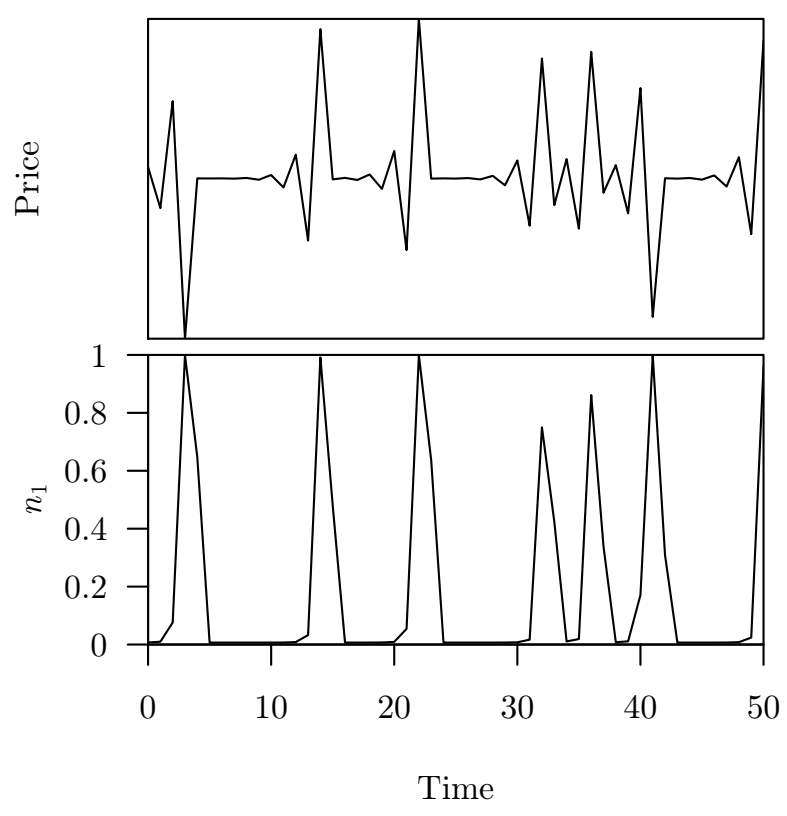

(b) Chaotic trajectory

Figure 3. Behaviour of the nonlinear cobweb with heterogeneous expectations. Parameters: $a=0, b=0.5, d=1.35, C=1$. In the bifurcation diagram (a), for small intensity of choice, $\beta$, the steady state is stable. Beyond a critical value, there is a two-period cycle. After infinite period doubling bifurcations, chaos occurs. The top panel of the trajectory (b) shows a chaotic path of price and the bottom panel the corresponding share of rational agents for $\beta=5$.

properties than with linear dynamics: we would expect that it would be more difficult to identify a pattern in forecasting errors. Hommes (1998) investigates this using the nonlinear cobweb models in Hommes (1991) and Brock and Hommes (1997). Hommes shows that forecasting errors all have a strong negative autocorrelation at the first lag, so, despite chaotic dynamics, nonlinear cobweb models with backward-looking expectations show little consistency between expectations and realisations.

\section{The competitive storage model}

In the simple linear model with a production lag, Muth's (1961) introduction of rational expectations restricts the dynamics to exogenous shocks around the steady state. Producers always plan to produce the same amounts and actual production is just a perturbation around this steady state level. In the same article, Muth models the effect of inventory speculation on price dynamics. He shows that the introduction of storage creates positive first-order serial correlation in prices. Speculation smoothes shocks over several periods, so the effect of one shock is spread across subsequent periods, causing positive serial correlation. On the other hand, the simple rational expectations and cobweb models generate zero and negative correlations. Both are inconsistent with the observations 
(Deaton and Laroque, 1992), which show evidence of high positive autocorrelation. Storage contributes to explaining one of the main features of commodity price series and reintroduces in the production lag model dynamic features other than exogenous shocks.

A technically correct treatment of storage is difficult, because it involves a regime-switching behaviour, since storage can be either positive or null. Muth gets around this problem by allowing negative storage. The same issue of inventory speculation under rational expectations was solved earlier by Gustafson (1958) with the non-negativity constraint but without supply reaction. Gustafson's work was really path-breaking. Not only he built a rational expectations storage model three years prior to Muth's publication, but he proposed as well pioneering numerical methods to solve dynamic models with binding constraints, methods that had to wait thirty years to be applied to the similar problem of optimal consumption with stochastic income (Zeldes, 1989). Gustafson anticipates much of what we now know about the rational expectations storage model. In particular, he recognises that in the absence of distortions an optimal governmental storage programme coincides with the behaviour of private storers in a free market.

The competitive storage model differs only slightly from the simple linear model under rational expectations, as can be seen from Table $4 .^{7}$ Storers carry-over positive stocks (12) when they expect the next period price to cover purchasing costs, marginal stocking costs (function $\phi$ of amount stocked $X_{t}$ ), opportunity costs (at the interest rate $r$ ) and depreciation (at the constant rate $\delta$ ). When the expected profit is negative, there are no stocks. The market clearing condition $\left(3^{\prime}\right)$ takes account of storage. Total supply consists of current production and stocks carried over from the previous period after depreciation, while demand includes consumption and carry over stocks. Introducing a non-negativity constraint makes the model analytically intractable. The rational expectations equation $\left(4^{\prime \prime}\right)$ is not a traditional algebraic expression. It captures the internal consistency of the model: that expectations must be consistent with all the information known about the model. Simple linear models with rational expectations can be solved using the undetermined coefficients method: the rational expectations condition is guessed at and its unknown coefficients are defined by solving the remaining equations. This strategy does not work for this model because of the complementarity condition (12). When storage is allowed to become negative, as in Muth (1961), an analytical solution exists. Finding a non-negative storage rule under rational expectations requires the resolution of a functional equation problem, which in turn requires numerical computations. $^{8}$

\footnotetext{
${ }^{7}$ Modern literature on price stabilisation or storage points out that a multiplicative disturbance would be more realistic than the additive disturbance assumed in (2). Productivity shocks (e.g., weather) are more likely to affect output in proportion to planned production levels than independently. This is important, because, under multiplicative disturbance, a rational producer does not react to the expected price but takes account of the inverse correlation between shocks and price. It also greatly affects the assessment of price stabilisation policies (Turnovsky, 1976, Wright, 1979). For the sake of simplicity, the usual assumption of additive disturbance is retained.

${ }^{8} \mathrm{~A}$ complete presentation of the corresponding numerical methods is beyond the scope of this paper. Briefly, the problem boils down to choosing a parametrisation for the rational expectations condition, usually a polynomial or a finite element interpolation. Parameters are found by iterative solving of the model on a grid of possible availabilities. At each iteration, parameters are updated to minimise the discrepancy with the rational expectations condition. Iterations can be generated by a simple successive approximation algorithm or a Newton-based solver.
} 
Table 4. The competitive storage model

\begin{tabular}{rlrl}
\hline$q_{t}^{D}$ & $=a-b p_{t}$ & & Consumption \\
$q_{t}^{S}$ & $=c+d \hat{p}_{t}+\epsilon_{t}$ & & Production \\
$q_{t}^{D}$ & $=q_{t}^{S}+(1-\delta) X_{t-1}-X_{t}$ & & Market equilibrium \\
$\hat{p}_{t}$ & $=\mathrm{E}_{t-1}\left(p_{t}\right)$ & & Rational expectations \\
$p_{t}$ & $\geq \frac{1-\delta}{1+r} \hat{p}_{t+1}-\phi^{\prime}\left(X_{t}\right) \quad \perp \quad X_{t} \geq 0$ & & $\left(3^{\prime}\right)$ \\
\end{tabular}

The implications of storage for market behaviour were studied by Gardner (1979) and Wright and Williams (1982a), and summarised in Williams and Wright (1991). The market for a storable commodity presents specific characteristics. It includes two different regimes. When stocks are exhausted (because the price is too high for storers to expect profits from carrying over grains), behaviour is similar to the simple rational expectations model: producers plan the same production whatever the availability and tomorrow's supply is independent of today's. With positive stocks, shocks are smoothed over several periods and prices are positively correlated. Stocks decrease expectations of high prices in the next period, so producers decrease their planned production according to the levels of stocks. These two regimes are depicted in Figure 4b. Below an availability close to the steady state level, market demand comes only from consumption because the high price deters storage. For higher total supply, demand for storage is added to consumption and makes market demand more reactive to price.

The possibility of storage affects the price distribution (Figure 4a). Prices are less volatile and their distribution is positively skewed. Storers take advantage of low prices to stockpile and, by doing so, reduce the probability of low prices. Compared to the situation without storage, the incidence of high prices diminishes, but not as much as for low prices, because stockouts happen when prices are high. The variance of the next period price increases with the current period price (Deaton and Laroque, 1992, p. 8), because the higher the current price, the lower the stocks and the less their damping effects. Beyond a threshold price there is no inventory to make a link between the current and the next period, so the price variance is constant. Storage creates price paths along which stable periods are interrupted by price spikes, corresponding to periods of stockout.

The competitive storage model under rational expectations has become the workhorse of neoclassical studies on price volatility. It has been extended in various directions. Its most simple version describes only inter-harvest fluctuations. But agricultural production is highly seasonal and must be stored at time of harvest to permit year round consumption. This creates predictable patterns in intra-annual prices. Prices should rise between harvests to cover storage costs (Samuelson, 1957). Between harvests prices do not just evolve deterministically, intra-seasonal periods are also periods of incoming information about future harvest conditions. Spot price and storage react to incoming news, because the storage arbitrage condition links the spot price to the expected price, even when

Detailed presentation of the algorithms used for storage problems can be found in Williams and Wright (1991), Miranda and Glauber (1995), Miranda (1997) and Miranda and Fackler (2002). 


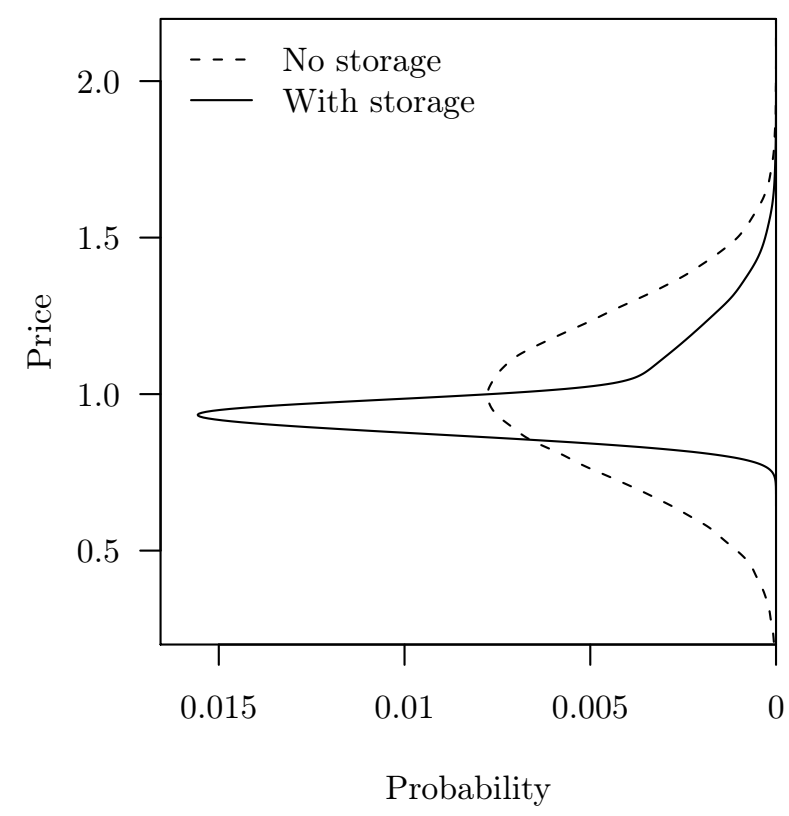

(a) Price distribution

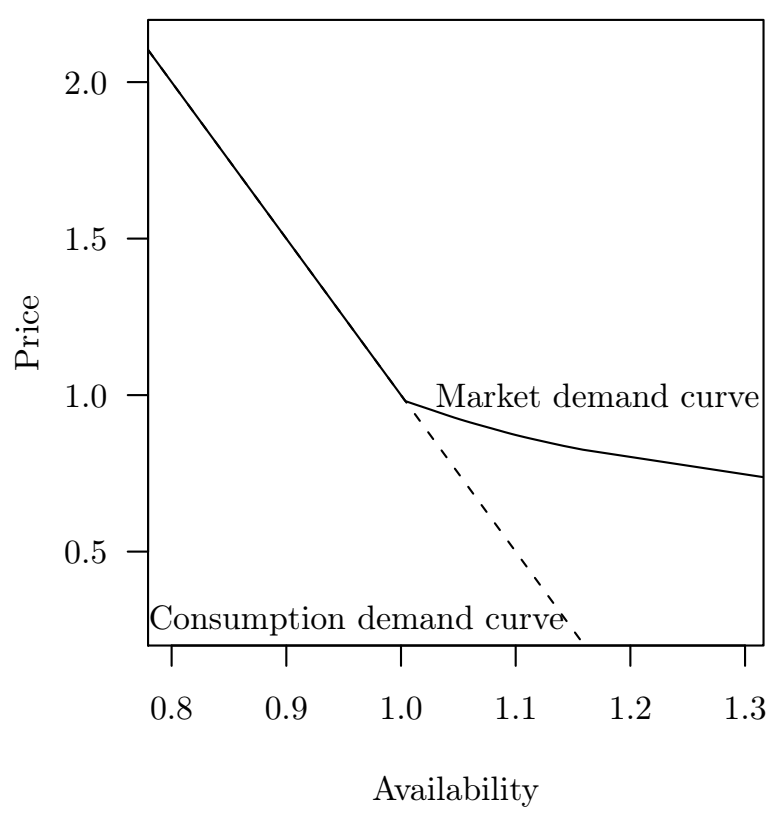

(b) Demand curves

Figure 4. Characterisation of the competitive storage model behaviour. Parameters: $a=1.2$, $b=0.2, c=0.8, d=0.2, \delta=1 \%, r=3 \%, \phi^{\prime}(X)=0.02, \epsilon \sim N\left(0,0.05^{2}\right)$. These parameters imply mean production and price at 1 when there is no shock, and supply and demand elasticities of 0.2 and -0.2 . In the demand curves (b), the dashed line is consumption demand, the solid line includes consumption demand and demand for carryover.

current market conditions are unchanged. The storage model was extended by Lowry et al. (1987), Williams and Wright (1991, Ch. 8), Chambers and Bailey (1996), Ng and Ruge-Murcia (2000) and Osborne (2004) to account for intra-seasonal shocks on demand or future supply.

Despite widespread protectionist policies, agricultural markets are very integrated and the international market often has a strong influence on domestic price volatility. The interaction between international trade and storage is studied in Williams and Wright (1991, Ch. 9) and Miranda and Glauber (1995). Makki et al. (1996) use a storage-trade model for studying export subsidies. Economically, trade and storage obey the same laws (Samuelson, 1957). In markets separated by space or time, the prices of a good may differ, but their difference must stay below the costs of shipping them to a more advantageous location or period. The two situations differ in that commodities can be stored only for future transactions, and arbitraging between periods is risky, while spatial arbitraging is less so. Trade generates the same kind of complementarity conditions as in equation (12), commodities are traded only when the trade cost is covered by the difference in international prices. ${ }^{9}$

Because goods flow from low price locations to higher price locations, trade, like storage, contributes to stabilising the market. Williams and Wright (1991) note that costless storage is more effective

\footnotetext{
${ }^{9}$ The trade aspect of storage-trade models is modelled in the spirit of spatial models in the manner of Takayama and Judge (1971).
} 
than costless trade for stabilising prices. This stabilising effect depends strongly on market features, storage and trade costs. If storage and trade are costly, an importing country does not carry-over stocks from one period to the next. Stocking imported goods incurs interest charges and depreciation on imported commodities. It is cheaper to wait for the next period harvest and, if necessary, decide

then to import. However, this conclusion holds only if trade is instantaneous. If trade takes time as in Coleman (2009), it can be rational to store imported commodities.

Two recent theoretical advances in the storage model are worthy of a mention. First, Bobenrieth et al. (2002) propose a storage model that differs slightly from the standard model in the tradition of Gustafson (1958). Its specific assumptions are that zero harvest has positive probability, and marginal utility at zero consumption is infinite. The implication is that stockout never occursas we observe in reality. There is no need to explicitly consider the non-negativity constraint on storage, since storers always find profitable to keep stocks to be able to profit from a zero harvest. Second, Nishimura and Stachurski (2009) describe the dynamics of a multisector model of commodity markets with storage. They prove the stationarity of the state process and the equivalence between the competitive equilibrium and the planner's problem. Such work could be valuable in the future given the important comovements between commodity prices.

\section{Endogenous or exogenous fluctuations?}

There are two modern, and opposing theories on agricultural price fluctuations. One rests on cobweb logic and views fluctuations as chaotic and as originating in forecasting errors. The other follows the rational expectations hypothesis stating that volatility results from real shocks, with price dynamics determined by the optimal reactions of agents (competitive storers, farmers) to these shocks. This literature raises two empirical questions. First, do the data require the introduction of nonlinearities in the models? Second, are fluctuations driven endogenously by forecasting errors or exogenously by real shocks?

For convenience, most of the empirical literature on expectations (Irwin and Thraen, 1994) uses linear models. The introduction of nonlinearities through storage, nonlinear supply curves or heterogeneous expectations brings important complexities to the estimation process (discussed below), and so must be justified. Several studies find that price dynamics exhibit significant nonlinearities, which leads to the linear framework being rejected. Both types of nonlinearity are found in the literature: nonlinearity in mean (Ng, 1996, Westerhoff and Reitz, 2005) and nonlinearity in variance (Yang and Brorsen, 1992, Shively, 1996, Beck, 2001, Chatrath et al., 2002, Adrangi and Chatrath, 2003). These findings confirm the need to introduce nonlinear features in the models.

What differentiates these two theories is the type of expectations: simple backward-looking, or rational. Two main strategies have been developed to identify how agents form their expectations (Irwin and Thraen, 1994, Nerlove and Bessler, 2001). In the first, when direct measures of expectations are unavailable, a structural model of supply and/or market equilibrium is required. This framework 
allows to confront several different expectations schemes. Orazem and Miranowski (1986) build such a model for three crops on the US market. Their estimations do not allow to conclude which expectations scheme is used by agents. In estimating models with private storage, Miranda and Glauber (1993a) and Frechette (1999) find evidence of a better fit from assuming agents endowed with rational expectations. But, in a survey of several of these studies, Irwin and Thraen (1994) are of the opinion that it is difficult to draw any robust conclusions about the formation of expectations from these estimations. For the same market, one study might opt for adaptive expectations, another for rational expectations and yet another might favour naive expectations. This lack of robustness might be explained by the linearity of all the models used in the works surveyed, the inability of the linear model to account for price dynamics being inherent.

The second strategy is to search directly for the expectations scheme in the expectations datawhether survey or experimental. In a survey of this literature, Irwin and Thraen (1994) highlight a lack of consensus regarding the rationality of expectations. Nerlove and Bessler (2001), however, are more positive. They find that agents try to adapt their forecasts according to the underlying stochastic process, but not in an optimal manner.

Given the lack of agreement about the formation of expectations, the rest of the paper adopts Prescott's (1977, p. 30) view that: "Like utility, expectations are not observed, and surveys cannot be used to test the rational expectations hypothesis. One can only test if some theory, whether it incorporates rational expectations or, for the matter, irrational expectations, is or is not consistent with observations". Thus, in what follows we assess the empirical performance of the two types of models.

\subsection{Estimations of competitive storage models}

The first estimation of a competitive storage model can be found in Deaton and Laroque (1992). ${ }^{10}$ Exploiting a model without supply reaction, from the storage arbitrage condition (12) without storage cost Deaton and Laroque deduce that there is a cutoff price $p^{*}$ above which the next period price is no longer linked to the current price. When the current price is so high that storage is not profitable, the next period expected price is constant and matches expectations of a simple rational expectations model without storage. The expected price function is given by

$$
\mathrm{E}_{t}\left(p_{t+1}\right)=\min \left(p^{*}, p_{t}\right) \frac{1+r}{1-\delta} .
$$

Deaton and Laroque estimate this equation using a generalised method of moments technique. They suppose that only prices are observable. This is very convenient because long price series are available for commodities, which is not true for other data (such as stocks, harvested areas). This approach was adopted in subsequent works. Deaton and Laroque use yearly prices for 13 primary commodities for the period 1900-1987. In equation (13), they estimate $p^{*}$ and $\gamma=(1+r) /(1-\delta)$.

\footnotetext{
${ }^{10}$ For a recent survey of empirical assessments of the storage model see Cafiero and Wright (2006).
} 
This estimation leads to mixed results. Predicted conditional means and variances conform to actual commodity prices. The model also explains price dynamics better than a simple random walk, but the estimates of $r+\delta$ are implausibly small and the cutoff price is often not well-determined, which would be consistent with infrequent stockouts.

This work paved the way to all further estimations. Chambers and Bailey (1996) use the same method to estimate a model using monthly data with periodic disturbances. Their conclusions are also mixed. Ng (1996) and Beck (2001) do not estimate the model, but they do test some of its empirical consequences, based on the findings in Deaton and Laroque (1992). Ng (1996) examines the existence of two regimes and the absence of serial correlation in the stockout regime. Using a threshold autoregressive model, she confirms an infrequent stockout regime but in many cases rejects the absence of serial correlation in this regime. ${ }^{11}$ Beck (2001) tests the autoregressive conditional heteroscedasticity $(\mathrm{ARCH})$ implied by inventory carryover. She confirms that storable commodities follow an $\mathrm{ARCH}$ process, while this is not the case for non-storable ones.

Deaton and Laroque $(1995,1996)$ propose another estimation method using pseudo-likelihood techniques. They reach the same conclusions as in their first paper, that speculative storage model cannot account for high levels of serial correlation. This claim, however, must be qualified. Michaelides and Ng (2000), using Monte Carlo simulations, compare several estimation methods for the storage model and show that the pseudo-maximum likelihood estimation tends to bias results. Cafiero and Wright (2006) cite other potential problems that influence the estimation (e.g., the inclusion of storage costs, the non-stationarity of price series, constant interest rate).

Under alternative assumptions, the model fits the data very well. For example, Miranda and Rui (1999) consider a different modelling of storage costs. They neglect any depreciation during storage, but introduce storage costs following the classical "supply of storage" theory (Kaldor, 1939, Working, 1949), which posits that costs are increasing with stock levels and negative for low stocks (i.e., convenience yield hypothesis). With a maximum likelihood estimation, they find that the storage model can explain the high autocorrelation of commodity prices very well. Cafiero et al. (2011) confirm the importance of storage costs modelling by applying Deaton and Laroque's (1995) estimation method to a constant marginal storage cost model. This specification improves the model ability to yield high price autocorrelation. They also show that Deaton and Laroque's (1995, 1996) estimations bias autocorrelation downward, because they approximate the equilibrium price function with an insufficient precision.

Estimations of agricultural price dynamics could be criticised on the grounds that, in most countries, public policies strongly affect prices. Miranda and Glauber (1993a) take account of the effects of public policies in estimating a rational expectations model for the US soybean market with private and government stockpiling. They use a log-linear approximation of the storage rule rather than the optimal rule (it is the optimal storage rule that creates the estimation problem solved by Deaton and Laroque). Miranda and Glauber show that the model behaves better under rational expectations

\footnotetext{
${ }^{11}$ Being based on a very limited number of observations, this latter finding is subject to caution.
} 
than with autoregressive expectations. They apply the same method for estimating intra-seasonal stockpiling behaviour in the potato market (Miranda and Glauber, 1993b).

In the case of the Ethiopian grain market, Osborne (2004) uses the speculative storage model to assess the effect of news about future production on market price. She builds an intra-seasonal model including the arrival of news (rainfall) related to the next harvest and estimates it using nonlinear least squares. Incorporating news improves the model, particularly its ability to represent the highly autocorrelated prices. However, the model fails to explain all seasonal variability.

Although the model is able qualitatively to represent the main features of agricultural prices (Peterson and Tomek, 2005), Deaton and Laroque $(1992,1996)$, who were the first to provide econometric estimates, were disappointed by the limited fit between the model and the data. Subsequent contributions are much more positive (Miranda and Rui, 1999, Cafiero et al., 2011), and given that the competitive storage models estimated were quite simple (they can often be reduced to one nonlinear equation) a better fit could be expected from more elaborate models.

\subsection{Empirical relevance of endogenous dynamics models}

Nonlinear cobweb models emerge not as a result of ex ante empirical observations, but as a response to the theoretical critiques of the linear cobweb model, and to demonstrate the possible existence of complex dynamics. Their empirical validation is very difficult due to the lack of mathematical tools to structurally estimate chaotic models (Barnett and He, 2001). We therefore considered other strategies including comparison with stylised facts, estimation of a related time-series model and testing for the presence of chaos in the time-series.

Do the predictions of nonlinear cobweb models agree with the stylised facts on agricultural prices? Studies such as Deaton and Laroque (1992), Yang and Brorsen (1992), Deaton (1999), Cashin et al. (2002) and Chatrath et al. (2002) identify some of these stylised facts. They show that agricultural

prices are not normally distributed, present high positive first-order autocorrelation, are positively skewed and display positive excess kurtosis. They show evidence of volatility clustering (generalised $\mathrm{ARCH}$ or $\mathrm{GARCH}$ ) and price cycles that are asymmetric, with slumps longer than upturns. The first generation of nonlinear cobweb models (Artstein, 1983, Jensen and Urban, 1984, Chiarella, 1988, Hommes, 1991, 1994) does not satisfy these properties. Figure 2b shows that their backwardlooking expectations create negative serial correlation in prices, because years of abundance and low prices are predicted to be followed by more abundant years, which limits planned production and leads eventually to high prices.

The only features common to models that produce nonlinear deterministic dynamics are a decision lag and backward-looking expectations. The empirical failure of some models does not preclude the empirical success of other models belonging to the same family. Heterogeneous agent models appear empirically more promising than simple nonlinear cobweb models: they provide a better fit with the stylised facts. The interaction between rational and backward-looking producers in Brock and 
Hommes (1997) creates the commonly observed succession of doldrums, booms and bust periods (Figure 3b top panel).

Voituriez (2001) studies the evolution of the palm-oil market from the early nineteenth century. Without carrying out a formal estimation, he shows that a nonlinear dynamics model, using agents with different expectations horizons, can be used for a qualitative representation of the successive periods of volatility experienced by this market when demand shifted from Europe to Asia, and supply shifted from Africa to Indonesia and Malaysia. To our knowledge, the only real econometric test of the heterogeneous agent models is by Westerhoff and Reitz (2005) who analyse a US commodity market, corn, driven not by supply and demand for the physical good, but by the interaction between technical and fundamental traders (as theorised in Brock and Hommes, 1998). They emphasise the financial speculative nature of such markets. They test their model by considering that the interaction between different traders can be captured with a smooth transition autoregressive GARCH (STAR-GARCH) model. Deviations from long-run equilibrium value attract more technical traders, justifying the smooth transition. The strategies of these traders produce time-varying effects justifying the GARCH components. The monthly data confirm the STAR-GARCH model. ${ }^{12}$

Since the direct estimation of nonlinear deterministic models is so difficult, we can test time-series data for the presence of chaos, characteristic of nonlinear cobweb models. Chatrath et al. (2002) and Adrangi and Chatrath (2003) adopt this strategy and confirm the existence of nonlinearity in price data, but not that this nonlinearity is caused by chaos. ${ }^{13}$

\subsection{Which model to explain price dynamics?}

In deciding among competing explanations we need to look at the empirical relevance of their counterfactual conclusions. Each type of model predicts a specific effect of trade on volatility. The rational expectations models imply a stabilising role of a larger market, while backward-looking models with no random shocks, predict a price dynamics not related to market size. In the context of early modern Europe, Persson (1999) shows how price volatility has declined with falling trade costs and reduced administrative barriers to trade. Jacks et al. (2011) confirm these findings. They show that world market integration brings less commodity volatility, and that periods of isolation due to wars or autarkic policies present more volatility. Sarris (2000) finds no evidence of increased volatility in the international cereal market, after the late 1960s. The tendency towards more open agricultural markets would be expected to lead to more stability, but there are other factors that might influence the markets (use of new high-yielding varieties, general decrease in public stocks), and prevent definitive conclusions. The evidence regarding the link between trade and volatility tends to confirm the hypothesis of a dynamics driven by external shocks that would be smoothed

\footnotetext{
${ }^{12}$ A STAR-GARCH model could be also compatible with the competitive storage model since its properties have been tested with an ARCH model and a self exciting threshold autoregressive (SETAR) model by Beck (2001) and $\mathrm{Ng}$ (1996).

${ }^{13}$ Given the lack of robustness of the tests for chaos for small sample sizes, finding evidence of chaos is difficult (Barnett et al., 1995, 1997).
} 
by the presence of a larger market. This does not confirm the rational expectations hypothesis, but it clearly rejects the pure endogenous dynamics model. A significant part of the dynamics is driven by external shocks.

Given this argument's longevity, the difficulty involved in empirically resolving the issue of endogenous and exogenous fluctuations is unsurprising. First generation agricultural price models, namely linear cobweb models for endogenous dynamics and rational expectations models for exogenous dynamics, have been proved to be observationally equivalent (Eckstein, 1984, 1985). Eckstein constructed a quadratic approximation of the rational expectations model, which embeds adjustment costs, and shows that it can be observationally equivalent to Nerlovian or simple cobweb models. We cannot prove similar equivalence for the second generation models, because they are not analytically tractable. But, since a chaotic trajectory can be confounded by random draws (a feature used by random number generators), it would not be surprising that a deterministic, nonlinear model could produce time series that are similar to the competitive storage model.

The remaining uncertainty should not outweigh the importance of previous findings: the significance of nonlinearity, the good fit of the rational expectations storage model, and the identification of a set of stylised facts. As shown above, most nonlinear models of endogenous dynamics do not comply with the stylised facts and must be rejected as relevant explanations. Also, evidence on the effects of trade on volatility shows that real shocks are important drivers of fluctuations. A tentative conclusion would be to assume support for the competitive storage model under rational expectations. The ability to decide which theory is best suited to representing agricultural markets becomes all the more critical when the competing theories lead to completely opposite conclusions regarding public intervention: one model represents Pareto-optimal dynamics; the other provides justification for public intervention.

\section{$6 \quad$ Public intervention in volatile markets}

Since the appropriateness of the public intervention depends on the cause of the fluctuations, the structural explanations of agricultural price dynamics proposed above should be essential for this issue. The distinction between endogenous and exogenous fluctuations, however, has framed the debate for positive rather than for normative questions. Most normative models assume real shocks and rational expectations.

\subsection{Marshallian analysis}

Modern welfare analysis of price stabilisation began with Waugh (1944), whose approach framed the debate for the next several decades. He analyse surpluses to show that consumers are better off under conditions of price instability than if prices are stabilised at no cost, at their arithmetic mean. This result is based on the flexibility provided to consumers by price variability. When the 
demand curve is downward sloping, users consume more at the lower prices and avoid the welfare losses of high prices by consuming less. Oi (1961) and Massell (1969), among others, use the same methodology.

This strand of the literature shows that it is possible to determine a priori the general welfare effects of a policy for producers and consumers. However, this finding is of limited relevance because an ideal stabilisation of prices at their arithmetic means is not feasible, and the costs of a stabilising policy are not included in the welfare evaluation. ${ }^{14}$ The last set of contributions to this methodology are by Wright (1979), Turnovsky et al. (1980) and Wright and Williams (1988b). Wright and Williams (1988b) derive a second order approximation of the expected equivalent variation for consumption stabilisation at the arithmetic mean, $\bar{q},{ }^{15}$

$$
\frac{\bar{q} P(\bar{q}, Y)}{2 \eta^{D}}\left[\frac{\theta}{\eta^{D}}\left(\eta^{Y}-\rho\right)+C-1\right] \Delta \sigma_{q}^{2}
$$

where $P(\bar{q}, Y)$ is the inverse demand function for income $Y, \eta^{D}$ and $\eta^{Y}$ are the price and income elasticities, $\theta$ is the budget share, $\rho$ is the coefficient of relative risk aversion, $C$ is the relative curvature of demand $\left(C=-\bar{q} P_{q q}(\bar{q}, Y) / P_{q}(\bar{q}, Y)\right)$ and $\Delta \sigma_{q}^{2}$ is the reduction in the variance of consumption.

The budget share of a single agricultural commodity in the developing countries can be above $10 \%$. This high budget share, combined with risk aversion, can induce important gains from consumption stabilisation in poor countries. In developed countries, the share is low, which means we can ignore the first term in the brackets. For these consumers, the curvature of demand drives the welfare effects. With a linear demand curve, $C=0$, consumers lose from quantity stabilisation. This result can be overturned for a different demand curvature. For constant demand elasticity, consumers gain if demand is inelastic. Producer welfare effects are also analysed in Wright (1979).

\subsection{A modern approach: introducing the role of expectations and stabilisation costs}

The previous analyses lack applicability, because ignoring the role of stabilisation costs can lead to misleading recommendations. Policy conclusions should be based on analyses that combine the reasons for price fluctuations and the costs of stabilisation.

Marshallian analyses describe consumer and producer behaviours as being derived from complete, but changing information. Turnovsky (1974) remarks that this is not appropriate for producers who have to plan production before knowing the selling price. Production lag implies a strong role for price expectations and alters the welfare results. Net gains from price stabilisation are higher under expected than actual prices, because stabilisation avoids resources being wasted when expectations are wrong. Turnovsky shows that the results of the Marshallian analyses hold when

\footnotetext{
${ }^{14}$ This analytical literature is surveyed in Wright (2001).

${ }^{15}$ Turnovsky et al. (1980) obtain a similar approximation for the stabilisation of prices at their arithmetic mean.
} 
introducing a decision lag with rational expectations; this is not the case for adaptive expectations, which introduce errors in resources allocation.

The fact that stabilisation can bring net gains should not be surprising, because it is provided by a costless technology within this framework (a "self-liquidating" buffer stock in Turnovsky, 1974). Introducing price stabilisation costs changes this. A costless technology does not exist, nor is it possible to perfectly stabilise markets. Storage does not allow perfect stabilisation, because a finite buffer stock cannot prevent stockouts.

The introduction of expectations and stabilisation costs makes the link to the previous sections. The two kinds of explanation for price volatility, exogenous and endogenous dynamics, give rise to different narratives concerning public intervention. In the first, within an exogenous dynamics model, the scarcity of agricultural products changes yearly with changes in yield, acreage and/or demand; price changes are normal economic adjustments to these new market conditions. Prices help to allocate a scarce resource to a more productive use. In traditional rational expectations storage models, agents are risk neutral, there is no market imperfection. Supply varies with weather shocks, optimal stock carryover and optimal reactions from farmers. Under these conditions, aggregate welfare cannot be improved by intervention. This optimality of competitive storage was emphasised in Gustafson (1958) and Gardner (1979), and formally proved by Scheinkman and Schechtman (1983). In the absence of market imperfections, a dynamic optimisation of the surplus can be recast as a set of decisions taken by individuals in a market context. ${ }^{16}$ So, in the framework of the competitive storage model, there is no rationale for public intervention.

This result does not hold for models following the cobweb logic. Cobweb models explain a significant part of the fluctuations as arising from systemic forecasting errors. The resulting price instability effectively reflects a change in scarcity, but this change is not the result of optimal producer reaction. Welfare optimality of the competitive equilibrium does not hold in this framework. The price path in cobweb-type models is socially suboptimal because farmers take decisions that are grounded not on the true expected variables but on backward-looking information, and production is not allocated in relation to expected scarcity.

As in the case of optimality of a decentralised equilibrium in general equilibrium theory, the social optimality of a market under rational expectations must not be taken as a positive statement which rules out any public intervention. This theory helps us to understand under which circumstances the interactions of private agents lead to socially optimal results when markets are volatile. Models with backward-looking expectations can be seen as a possible deviation from this benchmark. Other deviations, such as market incompleteness or externalities, are analysed later.

Starting from the rational expectations benchmark, several authors have examined various public interventions. Given that the competitive storage model is Pareto optimal without the introduction of market failures, any public policy that would stabilise prices in addition to private storage would

\footnotetext{
${ }^{16}$ This equivalence is the result of the application of the Second Welfare Theorem in a dynamic setting (Stokey and Lucas, 1989).
} 
lower welfare. Policy maker can infer some general conclusions about the effect of the available instruments. Miranda and Helmberger (1988) analyse in detail the introduction of a price band policy. Wright and Williams (1988a) compare the effects of floor price schemes, deficiency payments and extra-market disposal. Both papers find that short and long-run effects differ widely and may be of opposite signs. This result questions the reliability of comparative statics results obtained by highly stylised models in the tradition of Newbery and Stiglitz (1981). The short and long-run effects are different because stocks must be built-up before they can become operational. The additional demand for building the public stocks raises prices. On the asymptotic distribution, on the contrary, the higher availability weights on prices that are lower under a public stockpiling policy than without it. Because future losses are discounted, the short-run gains dominate and producers are expected to gains from the implementation of price-stabilisation schemes. The result is opposite if one looks only at long-run effects. The dynamic analysis of producers welfare must also consider the issue of capitalisation of their benefits in land price. ${ }^{17}$ Glauber et al. (1989) compare different approaches to market stabilisation. They point out that market stabilisation can be achieved efficiently through subsidised private storage. If the main concern is about producer price stabilisation, they show that deficiency payments are the best choice. Gardner and López (1996) show that interest-rate subsidies are not appropriate for stimulating private stockpiling and that subsidising direct storage is a better option. In the case of Indian foodgrain policy, Jha and Srinivasan (2001) demonstrate that market stabilisation is achieved more easily via trade under variable levies/subsidies than under autarky and price band policy.

Practical policy making cannot be based on these works. Even though many agricultural policies are known to be inefficient, they have often emerged initially to correct for some market imperfection. A fair policy assessment must take account of these imperfections, especially since this might completely reverse the more traditional conclusions. A few papers study the interaction of market imperfections and public intervention for price stabilisation; however they do not necessarily fit with the competitive storage framework. For convenience, they often use highly stylised rational expectations models.

The following sections discuss the justifications for public intervention based on four aspects: sensitivity of the results to the modelling assumptions; interventions in developing countries; interventions in developed countries; and the limited knowledge on the importance of market imperfections in relation to price dynamics.

\subsection{Sensitivity to modelling assumptions}

Some deviations from the canonical rational expectations model (with or without storage) have such strong effects that they may justify public intervention that is in complete opposition to conventional analyses. This is the case for risk-aversion under incomplete markets or backwardlooking expectations. These situations (Newbery and Stiglitz, 1984, Innes, 1990, Boussard et al.,

\footnotetext{
${ }^{17}$ More discussion on dynamic issues in agriculture can be found in Wright (1993).
} 
2006) correspond to second best situations (Lipsey and Lancaster, 1956), where attempts to satisfy some of the Paretian conditions (e.g., liberalising trade or suppressing agricultural policies) do not improve welfare. Policy recommendations when prices are volatile are very sensitive to the modelling context.

Innes (1990) makes this point, showing that, in an incomplete market setting with risk aversion, a public policy such as deficiency payments, usually thought of as welfare decreasing, can be Pareto improving. A similar story is told by Newbery and Stiglitz (1984), who analyse a general equilibrium model involving two goods and two countries. The production of one good is subject to random shocks. Autarky plays an income insurance role for risk-averse producers because domestic prices vary inversely with domestic production. In contrast, trade smoothes prices by averaging production shocks, but destroys the insurance effects since prices are linked to international rather than domestic conditions. This illustrates that price fluctuation is not the first concern of producers, who worry more about income fluctuation. The increased income risk deters them from producing a risky commodity and raises its price. Ultimately, welfare is lower under free trade than under autarky, because the reaction of risk-averse producers is stronger than the price stabilisation gains. Introducing risk aversion in an incomplete market can completely change the welfare effect of a policy.

The stabilising property of international trade is also sensitive to the modelling assumptions. If price fluctuations come mainly from forecasting errors, trade will not help to smooth idiosyncratic shocks, but, on the contrary, could increase instability. The study by Boussard et al. (2006) demonstrates this. They build a multi-country computable general equilibrium model with supply lagged one period, risk averse producers and Nerlovian expectations. They show that the movement in agricultural prices is amplified by market liberalisation, and welfare results go in opposite way compare to traditional expectations. Voituriez (2001) reaches a similar conclusion with his palm-oil chaotic market model. He shows that the increase in market size increases the instability of this market. The absence of exogenous shocks in both of these models explains these strong conclusions. Such a hypothesis is understandable for the examination of the theoretical effects of backward looking expectations on dynamics, as discussed in Section 2. But, in normative analysis, the focus on forecast errors may lead to spurious conclusions, which can be reversed by considering exogenous shocks. For example, by introducing both Nerlovian expectations and random shocks in a partial equilibrium model, Tyers and Anderson (1992) find a stabilising effect of increased market integration, because a wider market allows the shocks to be averaged out, despite the forecasting errors.

\subsection{Rationale for public intervention in developing countries}

Distinctions can be made in terms of the policy recommendations directed to developed and developing countries. Risk aversion has a significant effect for economically poorer consumers, who are required to allocate a large share of their budget to the purchase of staple food (see equation (14)). Newbery (1989) provides an analytical framework for analysing public intervention when consumers 
are risk-averse and are required to spend a large share of their income on staple foods. Newbery determines the conditions that make it beneficial to stockpile above the level achieved in a competitive market, and shows that consumer protection can also be achieved through the sale of rations at low prices.

In poor societies, low prices for staple foods are essential for social order. Evidence from early modern England shows that the number of thefts rose during dearth periods (Walter and Wrightson, 1976). The food crisis in poor countries in the first part of 2008 culminated in hunger riots in Cameroon, Côte d'Ivoire and Haiti. Price stability generates gains that are not exclusive to grain storers (Persson, 1996). These externalities are a traditional motivation for public intervention. Private storage on its own cannot provide a socially optimal level of stability in the presence of externalities.

Externalities created by positive deviations from mean prices are discussed in Gardner (1979). He proposes a method for finding an optimal storage rule, which could be implemented by a public agency, in response to this type of externality. This would crowd out all private speculative carryover because the optimal stockpiling would increase the carryover to a point where expected returns would be negative (optimal storage is higher where there are external benefits to price stability). The traditional practice of public storage, however, does not follow an optimal storage rule, but a buffer stock with a price band rule, which leaves room for speculative stockpiling. Another way of correcting this externality would be to subsidise private storage, but neither of these two interventions, price band or subsidy, even if carefully designed, can substitute for an optimal storage rule. In a real context, the externality and numerous model parameters would not be measurable, which would call for robust storage policies that were not over sensitive to ill-known aspects. Gardner (1979) shows that a small buffer stock is the best solution. ${ }^{18}$

Even in the absence of externalities, social disorder presents government with a commitment problem. If government cannot commit to not imposing a policy that would prevent stock holders from benefiting from high prices (e.g., a price ceiling, an export tax or a seizure of existing stocks), stock holders can expect limited profits from their activities, and private storage will be reduced below the optimal level. ${ }^{19}$ When grain stock holders are blamed for hoarding and making money out of people's hunger, and when political stability rests critically on the availability of staples, it is difficult for governments not to react against private stockpiling in times of grain shortages. In this case, public storage would be required to reach a social optimum. Wright and Williams (1982b) provide a formal treatment of such a situation in the case of disruption to oil supplies. They show that public stocks can alleviate the adverse effects of lack of government commitment to not imposing a price ceiling.

In addition to the above theoretical rationales for intervention, we should consider a practical issue:

\footnotetext{
${ }^{18}$ Concerns about the robustness of policies to model mis-specification have been the object of recent work in macroeconomic dynamics using new tools from robust control theory (Hansen and Sargent, 2007). Gardner (1979) is a crude test of robustness that does not rely on these tools.

${ }^{19}$ During the 2008 food crisis, numerous developing countries adopted such policies, especially for the rice market.
} 
the most important staple for developing countries is also the most subject to extreme behaviours. Rice is thinly traded on international markets ( $7 \%$ of total production). And at the first signs of price tensions, the exporters impose export controls to ease their domestic markets. In the 19731974 crisis, such export bans made the world rice market disappeared for nine months (Timmer, 2010). The 2007-2008 crisis saw the same behaviour with most exporters closing successively their markets, fuelling in this way the panic in the rice market (Slayton, 2009). Given this lack of commitment of exporters to being reliable suppliers, importing countries should consider the case for national strategic reserves (Wright, 2012). Following the 1970s oil crisis, the related issue of managing strategic petroleum reserves in case of supply disruption have been analysed in several papers (e.g., Wright and Williams, 1982b, Murphy et al., 1987).

\subsection{Intervention in developed countries?}

In rich countries, agricultural price instability is of more limited concern to consumers, who devote only a limited share of their budgets to agricultural commodities. The rationale for public intervention in these countries will be based more on imperfections in the storage and production markets. Market imperfections in agricultural markets are numerous, but are rarely introduced in models that account for both the origins of price fluctuations and the public policies designed to mitigate them. Analyses of farm programmes addressing instability concentrate on economic costs by comparing policies to the competitive storage benchmark. ${ }^{20}$ Hence, the discussion below highlights only the possible effects of market imperfections in developed countries.

In the storage model, both producers and storers may be concerned by risk aversion. Storers will be seen as risk neutral if they can hedge their position on futures markets (see Williams and Wright, 1991, p. 28). Holthausen (1979) and Feder et al. (1980) demonstrate the following separation property: when futures markets are available, a risk-averse firm under price uncertainty behaves as if it were risk neutral. Its risk aversion only affects its position in the futures market. This separation between productive choice and hedging does not hold for farmers who face both price and output uncertainty (McKinnon, 1967) ${ }^{21}$ Hence, welfare analyses of agricultural policies should take account of farmers' risk-aversion. Lence (2009) is the only example of a storage model that includes risk-averse producers. He demonstrates the counterintuitive effect of the introduction of a futures market for risk-averse producers. While such a policy is often thought of as helpful to producers, Lence finds that producers lose from the creation of a futures market while consumers gain. Producers who hedge part of their production are more responsive to changes in market conditions. Their output is higher, which lowers prices and profits. As a result, their welfare is lower.

\footnotetext{
${ }^{20}$ As noted by Leathers and Chavas (1986), this issue is not specific to price volatility analysis. Analyses of agricultural policies focus on the economic costs of policies without introducing the underlying market imperfections that were their justifications.

${ }^{21}$ Moreover, futures cannot completely remove price uncertainty because of basis risk, i.e., the spread between the futures price and the producer price.
} 
The agricultural production sector is often regarded as a good example of a perfectly competitive market. This is not true of the upstream and downstream sectors. The storage and marketing of grains cannot always be seen as competitive markets. Some studies address the issue of market structure. Newbery (1984) analyses the case of producers' market power. Williams and Wright (1991, Ch. 11) treat the case of market power over storage and show that storage is lower under monopoly than in a competitive market. McLaren (1999) extends the analysis to an oligopoly with restricted entry. McLaren confirms Williams and Wright's results of a level of storage increasing with the level of competition, and thus decreasing price volatility. These results contradict the popular tenet that market power over storage explains the price spikes caused by excessive hoarding by non-competitive storers.

Leathers and Chavas (1986) examine the effects of price uncertainty on farm default. Because of market incompleteness and price shocks, indebted farmers may default on their loans. Such defaults are costly to society because of the immobility of capital assets. Public intervention could improve market outcomes, but the design of such policies would be challenging, because of the need that adverse economic incentives were not being created.

Thirty years ago, Gardner (1979, p. 150) noted that "the current state of knowledge does not permit the specification of [a socially optimal stockpiling] regime". The position is not better today. Since his work, several justifications for public intervention have been proposed. But robust conclusions, including both the reasons for price instability and the public interventions relevant for the market imperfections, should only be based on empirically relevant models. These two aspects are still being studied separately. We can say tentatively that imperfections in agricultural markets justify public intervention, at least in developing countries, to mitigate price instabilities. In developed countries, since public policies are studied in an optimal world that does not justify any intervention, we do not know what would be the best way to stabilise imperfect markets. Most of the applied studies of public intervention to achieve price stability (e.g., Makki et al., 1996, 2001, Jha and Srinivasan, 1999, 2001, Srinivasan and Jha, 2001, Lence and Hayes, 2002, Brennan, 2003) do not consider market imperfections, with the exception of Brennan (2003), who examines the effect of an imperfect credit market for private storers.

\subsection{The missing connection between price dynamics and market imperfections}

The agricultural sector is not isolated from the rest of the economy and its price dynamics can be affected by non-agricultural factors, such as the business cycle. For instance, Andrews and Rausser (1986) explain how the macroeconomic effects on the agricultural sector were an important justification for the agricultural policies introduced in the first half of the twentieth century.

A possible link between macroeconomic conditions and commodity prices is described in the overshooting theory proposed by Frankel (1986). He introduces a model that is similar to Dornbusch's (1976) model. It assumes that agricultural prices are flexible, while other prices are sticky. An unexpected rise in the money supply, which should lead to a nominal price increase, results in a decrease 
in real interest rates due to price stickiness. As a result of the storage arbitrage condition (12), if the next period prices change according to the new inflation expectations, the fall in interest rates will result in an overshooting of the current-period price. This conclusion has been criticised on theoretical grounds (Obstfeld, 1986, Lai et al., 2005), but Frankel's work provides a framework for studying monetary impacts on commodity behaviour, whether over or under shooting. Several empirical studies confirm the link between these markets and monetary variables (Chambers and Just, 1982, Chambers, 1984, Frankel and Hardouvelis, 1985, Orden and Fackler, 1989, Robertson and Orden, 1990).

The existence of monetary effects implies that agricultural prices do not always match market scarcity. Because of imperfections in non-agricultural markets, the agricultural sector price path is not optimal. The link between market imperfections and observed price dynamics is rarely made, except in the case of overshooting caused by monetary effects. But if market imperfections really affect agents' behaviour to the point of justifying public intervention, they should be reflected in price dynamics, which should differ from those in efficient markets. For other aspects than monetary shocks, the possibility that market imperfections may explain commodity dynamics and lead to a better fit remains an open question.

\section{Conclusion and perspectives}

Economic understanding of agricultural price fluctuations has improved greatly since the beginning of the 1980s. This better understanding began with critiques of the cobweb model. One of the newer explanations for these fluctuations adopts the cobweb logic of endogenous dynamics, showing that, in the context of chaotic dynamics, relying on rule-of-thumb expectations is not such a bad choice. Another explanation follows the path of rational expectations and emphasises the importance of storage for explaining price dynamics. The theory has improved, but the question of the origin of volatility has not been definitively settled.

Empirical tests of the storage model under rational expectations confirm its relevance for qualitatively explaining many of the stylised facts in this area. And contrary to first econometric results, which led to mixed conclusions, recent estimates find that the storage model provides a very good fit. It is more difficult to test the alternative explanation of endogenous dynamics, because it gives rise to chaotic models that cannot be estimated. But most endogenous dynamics explanations do not generate price series that are consistent with the stylised facts, namely positive serial correlation and positive skewness, a failure that also applies to the linear cobweb model. We can tentatively conclude that the rational expectations scheme is better supported.

If agricultural price volatility is driven by real shocks in an economy populated by rational and risk-neutral agents, there is no public intervention that can improve the welfare. Such a strong

conclusion requires to be tempered. Since this conclusion is based on there being a complete absence of market failure, the rational expectations model might be seen better as a normative benchmark 
than an accurate description of reality. In poor countries, consumer risk aversion and the social externalities of high food prices make a strong case for public intervention in grain markets. In developed countries, the case for intervention is less clear. Introducing producer risk aversion or liquidity constraints in the storage model would provide a rationale for public intervention, but this is not explored in the literature.

To define some next research steps, we can draw some parallels with the recent history of macrodynamics literature. Macro-dynamics presents some similarities with agricultural price dynamics. Both fields aim at explaining the origins of economic fluctuations and designing policies to mitigate their effects.

The real business cycle model of Kydland and Prescott (1982) has become a workhorse for the study of macroeconomic fluctuations since the early 1980s. This canonical model was extended in various ways in order to try to deal with some of its empirical limitations such as lack of persistence in the time series, or the overemphasis on total factor productivity shocks, which implies that recessions are times of technological regress. The standard models now include nominal (prices and wages) and real rigidities (e.g., adjustment costs and habit formation), and monetary shocks (Rebelo, 2005, Woodford, 2009). However, there is no similar path in agricultural economics. The competitive storage model has not become the corner stone for series of works that include other features that can be tested for their effects on dynamics. Instead, most externalities have been analysed within a static framework and their dynamic effects are unknown.

To follow the business cycle programme in agricultural economics, the models should be extended, and econometrically validated, to include externalities and interactions between sectors. Recent papers (Lence and Hayes, 2002, Osborne, 2004, Park, 2006, Lence, 2009) have made some efforts to extend the storage model to more empirically relevant situations. However, these developments are more challenging in the context of the storage model than when applied to macroeconomic models. Macroeconomic models are usually linearised, or approximated at small orders, around the steady state, which makes them extendable to medium/high scale problems. The storage model is strongly nonlinear, which rules out such approximations. The available numerical methods suffer from the "curse of dimensionality", namely the exponential rise in computing time when problem dimensions increase. New developments in computational methods, such as sparse grid interpolation (Krueger and Kubler, 2004), might help to overcome this problem.

Given the on-going debate over backward-looking versus rational expectations, another improvement would be to examine more deeply the question of expectations building and information. The opposition between backward-looking and rational expectations models is surely too simple. Rational agents can devote a limited attention to all incoming information and so will take decisions that are non-optimal with respect to a full information benchmark (Sims, 2006). Even fully informed agents will have to achieve coordination on the rational expectations equilibrium, which might prove difficult. For example, following the eductive stability concept of Guesnerie (1992), Guesnerie and Rochet (1993) and Calvo-Pardo (2009) studied expectations coordination in traditional agricultural market settings. Both studies show that international trade or speculation on futures market may 
be destabilising when there is no Walrasian auctioneer and agents must coordinate by forecasting the forecasts of others.

\section{References}

Aadland, D. (2004). Cattle cycles, heterogeneous expectations and the age distribution of capital. Journal of Economic Dynamics and Control, 28(10), 1977-2002.

Adrangi, B. and Chatrath, A. (2003). Non-linear dynamics in futures prices: evidence from the coffee, sugar and cocoa exchange. Applied Financial Economics, 13(4), 245-256.

Akerman, G. (1957). The cobweb theorem: A reconsideration. The Quarterly Journal of Economics, 71(1), 151-160.

Andrews, M. S. and Rausser, G. C. (1986). Some political economy aspects of macroeconomic linkages with agriculture. American Journal of Agricultural Economics, 68(2), 413-417.

Artstein, Z. (1983). Irregular cobweb dynamics. Economics Letters, 11(1-2), 15-17.

Barnett, W. A., Gallant, A. R., Hinich, M. J., Jungeilges, J. A., Kaplan, D. T. and Jensen, M. J. (1995). Robustness of nonlinearity and chaos tests to measurement error, inference method, and sample size. Journal of Economic Behavior ES Organization, 27(2), 301-320.

Barnett, W. A., Gallant, A. R., Hinich, M. J., Jungeilges, J. A., Kaplan, D. T. and Jensen, M. J. (1997). A single-blind controlled competition among tests for nonlinearity and chaos. Journal of Econometrics, 82(1), 157-192.

Barnett, W. A. and He, Y. (2001). Unsolved econometric problems in nonlinearity, chaos, and bifurcation. Central European Journal of Operations Research, 9, 147-182.

Baumol, W. J. and Quandt, R. E. (1964). Rules of thumb and optimally imperfect decisions. The American Economic Review, 54(2), 23-46.

Beck, S. (2001). Autoregressive conditional heteroscedasticity in commodity spot prices. Journal of Applied Econometrics, 16(2), 115-132.

Bobenrieth, E. S. A., Bobenrieth, J. R. A. and Wright, B. D. (2002). A commodity price process with a unique continuous invariant distribution having infinite mean. Econometrica, 70(3), 1213-1219.

Boussard, J.-M. (1996). When risk generates chaos. Journal of Economic Behavior \& Organization, 29(3), 433-446.

Boussard, J.-M., Gerard, F., Piketty, M. G., Ayouz, M. and Voituriez, T. (2006). Endogenous risk and long run effects of liberalization in a global analysis framework. Economic Modelling, 23(3), $457-475$.

Brennan, D. (2003). Price dynamics in the Bangladesh rice market: implications for public intervention. Agricultural Economics, 29(1), 15-25.

Brock, W. A. and Hommes, C. H. (1997). A rational route to randomness. Econometrica, 65(5), 1059-1096. 
Brock, W. A. and Hommes, C. H. (1998). Heterogeneous beliefs and routes to chaos in a simple asset pricing model. Journal of Economic Dynamics and Control, 22(8-9), 1235-1274.

Buchanan, N. S. (1939). A reconsideration of the cobweb theorem. The Journal of Political Economy, $47(1), 67-81$.

Cafiero, C., Bobenrieth, E. S. A., Bobenrieth, J. R. A. and Wright, B. D. (2011). The empirical relevance of the competitive storage model. Journal of Econometrics, 162(1), 44-54.

Cafiero, C. and Wright, B. D. (2006). Is the storage model a 'closed' empirical issue? The empirical ability of the storage model to explain price dynamics. In A. Sarris and D. Hallam (eds.) Agricultural Commodity Markets and Trade. New Approaches to Analyzing Market Structure and Instability, chapter 4, (pp. 89-114). Northampton: FAO/Edward Elgar.

Calvo-Pardo, H. (2009). Are the antiglobalists right? Gains-from-trade without a Walrasian auctioneer. Economic Theory, 38(3), 561-592.

Cashin, P., McDermott, C. J. and Scott, A. (2002). Booms and slumps in world commodity prices. Journal of Development Economics, 69(1), 277-296.

Chambers, M. J. and Bailey, R. E. (1996). A theory of commodity price fluctuations. The Journal of Political Economy, 104(5), 924-957.

Chambers, R. G. (1984). Agricultural and financial market interdependence in the short run. American Journal of Agricultural Economics, 66(1), 12-24.

Chambers, R. G. and Just, R. E. (1982). An investigation of the effect of monetary factors on agriculture. Journal of Monetary Economics, 9(2), 235-247.

Chatrath, A., Adrangi, B. and Dhanda, K. K. (2002). Are commodity prices chaotic? Agricultural Economics, 27(2), 123-137.

Chiarella, C. (1988). The cobweb model: Its instability and the onset of chaos. Economic Modelling, $5(4), 377-384$.

Coleman, A. (2009). A model of spatial arbitrage with transport capacity constraints and endogenous transport prices. American Journal of Agricultural Economics, 91(1), 42-56.

Commendatore, P. and Currie, M. (2008). The cobweb, borrowing and financial crises. Journal of Economic Behavior \& Organization, 66(3-4), 625-640.

Deaton, A. (1999). Commodity prices and growth in Africa. The Journal of Economic Perspectives, 13(3), 23-40.

Deaton, A. and Laroque, G. (1992). On the behaviour of commodity prices. Review of Economic Studies, 59(1), 1-23.

Deaton, A. and Laroque, G. (1995). Estimating a nonlinear rational expectations commodity price model with unobservable state variables. Journal of Applied Econometrics, 10, S9-S40.

Deaton, A. and Laroque, G. (1996). Competitive storage and commodity price dynamics. The Journal of Political Economy, 104(5), 896-923.

Dornbusch, R. (1976). Expectations and exchange rate dynamics. The Journal of Political Economy, 
84(6), 1161-1176.

Eckstein, Z. (1984). A rational expectations model of agricultural supply. The Journal of Political Economy, 92(1), 1-19.

Eckstein, Z. (1985). The dynamics of agriculture supply: A reconsideration. American Journal of Agricultural Economics, 67(2), 204-214.

Ezekiel, M. (1938). The cobweb theorem. The Quarterly Journal of Economics, 52(2), 255-280.

Feder, G., Just, R. E. and Schmitz, A. (1980). Futures markets and the theory of the firm under price uncertainty. The Quarterly Journal of Economics, 94(2), 317-328.

Frankel, J. A. (1986). Expectations and commodity price dynamics: The overshooting model. American Journal of Agricultural Economics, 68(2), 344-348.

Frankel, J. A. and Hardouvelis, G. A. (1985). Commodity prices, money surprises and Fed credibility. Journal of Money, Credit, and Banking, 17(4), 425-438.

Frechette, D. L. (1999). The supply of storage under heterogeneous expectations. Journal of Agricultural \& Applied Economics, 31(3), 461-474.

French, B. C. and Matthews, J. L. (1971). A supply response model for perennial crops. American Journal of Agricultural Economics, 53(3), 478-490.

Gardner, B. L. (1979). Optimal Stockpiling of Grain. Lexington, Mass.: Lexington Books.

Gardner, B. L. and López, R. (1996). The inefficiency of interest-rate subsidies in commodity price stabilization. American Journal of Agricultural Economics, 78(3), 508-516.

Gilbert, C. L. (1996). International commodity agreements: An obituary notice. World Development, $24(1), 1-19$.

Glauber, J. W., Helmberger, P. G. and Miranda, M. J. (1989). Four approaches to commodity market stabilization: A comparative analysis. American Journal of Agricultural Economics, 71(2), 326-337.

Goeree, J. K. and Hommes, C. H. (2000). Heterogeneous beliefs and the non-linear cobweb model. Journal of Economic Dynamics and Control, 24(5-7), 761-798.

Guesnerie, R. (1992). An exploration of the eductive justifications of the rational-expectations hypothesis. The American Economic Review, 82(5), 1254-1278.

Guesnerie, R. and Rochet, J.-C. (1993). (De)stabilizing speculation on futures markets: An alternative view point. European Economic Review, 37(5), 1043-1063.

Gustafson, R. L. (1958). Carryover Levels for Grains: A Method for Determining Amounts that are Optimal Under Specified Conditions. Technical Bulletin 1178, US Dept. of Agriculture.

Hansen, L. P. and Sargent, T. J. (2007). Robustness. Princeton: Princeton University Press.

Headey, D. and Fan, S. (2008). Anatomy of a crisis: the causes and consequences of surging food prices. Agricultural Economics, 39(s1), 375-391.

Holthausen, D. M. (1979). Hedging and the competitive firm under price uncertainty. The American 
Economic Review, 69(5), 989-995.

Hommes, C. H. (1991). Adaptive learning and roads to chaos: The case of the cobweb. Economics Letters, 36(2), 127-132.

Hommes, C. H. (1994). Dynamics of the cobweb model with adaptive expectations and nonlinear supply and demand. Journal of Economic Behavior 83 Organization, 24(3), 315-335.

Hommes, C. H. (1998). On the consistency of backward-looking expectations: The case of the cobweb. Journal of Economic Behavior 63 Organization, 33(3-4), 333-362.

Hommes, C. H. (2006). Heterogeneous agent models in economics and finance. In L. Tesfatsion and K. L. Judd (eds.) Agent-based Computational Economics, volume 2, part 1 of Handbook of Computational Economics, chapter 23, (pp. 1109-1186). Amsterdam: Elsevier.

Hooton, F. G. (1950). Risk and the cobweb theorem. The Economic Journal, 60(237), 69-80.

Innes, R. (1990). Government target price intervention in economies with incomplete markets. The Quarterly Journal of Economics, 105(4), 1035-1052.

Irwin, S. H. and Thraen, C. S. (1994). Rational expectations in agriculture? A review of the issues and the evidence. Review of Agricultural Economics, 16(1), 133-158.

Jacks, D. S., O'Rourke, K. H. and Williamson, J. G. (2011). Commodity price volatility and world market integration since 1700. Review of Economics and Statistics, 93(3), 800-813.

Jensen, R. V. and Urban, R. (1984). Chaotic price behavior in a non-linear cobweb model. Economics Letters, 15(3-4), 235-240.

Jha, S. and Srinivasan, P. V. (1999). Grain price stabilization in India: Evaluation of policy alternatives. Agricultural Economics, 21(1), 93-108.

Jha, S. and Srinivasan, P. V. (2001). Food inventory policies under liberalized trade. International Journal of Production Economics, 71(1-3), 21-29.

Kaldor, N. (1939). Speculation and economic stability. The Review of Economic Studies, 7(1), 1-27.

Krueger, D. and Kubler, F. (2004). Computing equilibrium in OLG models with stochastic production. Journal of Economic Dynamics and Control, 28(7), 1411-1436.

Kydland, F. E. and Prescott, E. C. (1982). Time to build and aggregate fluctuations. Econometrica, 50(6), 1345-1370.

Labys, W. C. (2006). Modeling And Forecasting Primary Commodity Prices. Aldershot: Ashgate.

Lai, C. C., Hu, S. W. and Fan, C. P. (2005). The overshooting hypothesis of agricultural prices: The role of asset substitutability. Journal of Agricultural and Resource Economics, 30(1), 128-150.

Lasselle, L., Svizzero, S. and Tisdell, C. (2005). Stability and cycles in a cobweb model with heterogeneous expectations. Macroeconomic Dynamics, 9(5), 630-650.

Leathers, H. D. and Chavas, J.-P. (1986). Farm debt, default, and foreclosure: An economic rationale for policy action. American Journal of Agricultural Economics, 68(4), 828-837.

Lence, S. H. (2009). Do futures benefit farmers? American Journal of Agricultural Economics, 


$$
\text { 91(1), 154-167. }
$$

Lence, S. H. and Hayes, D. J. (2002). U.S. farm policy and the volatility of commodity prices and farm revenues. American Journal of Agricultural Economics, 84(2), 335-351.

Lipsey, R. G. and Lancaster, K. (1956). The general theory of second best. The Review of Economic Studies, 24(1), 11-32.

Lowry, M., Glauber, J. W., Miranda, M. J. and Helmberger, P. G. (1987). Pricing and storage of field crops: A quarterly model applied to soybeans. American Journal of Agricultural Economics, 69(4), 740-749.

Makki, S. S., Tweeten, L. G. and Miranda, M. J. (1996). Wheat storage and trade in an efficient global market. American Journal of Agricultural Economics, 78(4), 879-890.

Makki, S. S., Tweeten, L. G. and Miranda, M. J. (2001). Storage-trade interactions under uncertainty-implications for food security. Journal of Policy Modeling, 23(2), 127-140.

Massell, B. F. (1969). Price stabilization and welfare. The Quarterly Journal of Economics, 83(2), 284-298.

McKinnon, R. I. (1967). Futures markets, buffer stocks, and income stability for primary producers. The Journal of Political Economy, 75(6), 844-861.

McLaren, J. (1999). Speculation on primary commodities: The effects of restricted entry. The Review of Economic Studies, 66(4), 853-871.

Michaelides, A. and Ng, S. (2000). Estimating the rational expectations model of speculative storage: A Monte Carlo comparison of three simulation estimators. Journal of Econometrics, 96(2), 231-266.

Miranda, M. J. (1997). Numerical strategies for solving the nonlinear rational expectations commodity market model. Computational Economics, 11(1-2), 71-87.

Miranda, M. J. and Fackler, P. L. (2002). Applied Computational Economics and Finance. Cambridge: MIT Press.

Miranda, M. J. and Glauber, J. W. (1993a). Estimation of dynamic nonlinear rational expectations models of primary commodity markets with private and government stockholding. The Review of Economics and Statistics, 75(3), 463-470.

Miranda, M. J. and Glauber, J. W. (1993b). Intraseasonal demand for fall potatoes under rational expectations. American Journal of Agricultural Economics, 75(1), 104-112.

Miranda, M. J. and Glauber, J. W. (1995). Solving stochastic models of competitive storage and trade by Chebychev collocation methods. Agricultural and Resource Economics Review, 24(1), $70-77$.

Miranda, M. J. and Helmberger, P. G. (1988). The effects of commodity price stabilization programs. The American Economic Review, 78(1), 46-58.

Miranda, M. J. and Rui, X. (1999). An empirical reassessment of the commodity storage model, mimeo, The Ohio State University. 
Murphy, F. H., Toman, M. A. and Weiss, H. J. (1987). A stochastic dynamic Nash game analysis of policies for managing the strategic petroleum reserves of consuming nations. Management Science, 33(4), 484-499.

Muth, J. F. (1961). Rational expectations and the theory of price movements. Econometrica, 29(3), $315-335$.

Nerlove, M. (1958). Adaptive expectations and cobweb phenomena. The Quarterly Journal of Economics, 72(2), 227-240.

Nerlove, M. and Bessler, D. A. (2001). Expectations, information and dynamics. In B. L. Gardner and G. C. Rausser (eds.) Agricultural Production, volume 1, part 1 of Handbook of Agricultural Economics, chapter 3, (pp. 155-206). Amsterdam: Elsevier.

Newbery, D. M. G. (1984). Commodity price stabilization in imperfect or cartelized markets. Econometrica, 52(3), 563-578.

Newbery, D. M. G. (1989). The theory of food price stabilisation. The Economic Journal, 99(398), $1065-1082$.

Newbery, D. M. G. and Stiglitz, J. E. (1981). The Theory of Commodity Price Stabilization: A Study in the Economics of Risk. Oxford: Clarendon Press.

Newbery, D. M. G. and Stiglitz, J. E. (1984). Pareto inferior trade. Review of Economic Studies, $51(1), 1-12$.

$\mathrm{Ng}, \mathrm{S}$. (1996). Looking for evidence of speculative stockholding in commodity markets. Journal of Economic Dynamics and Control, 20(1-3), 123-143.

Ng, S. and Ruge-Murcia, F. J. (2000). Explaining the persistence of commodity prices. Computational Economics, 16(1-2), 149-171.

Nishimura, K. and Stachurski, J. (2009). Equilibrium storage with multiple commodities. Journal of Mathematical Economics, 45(1-2), 80-96.

Obstfeld, M. (1986). Overshooting agricultural commodity markets and public policy: Discussion. American Journal of Agricultural Economics, 68(2), 420-421.

Oi, W. (1961). The desirability of price instability under perfect competition. Econometrica, 29(1), $58-64$

Onozaki, T., Sieg, G. and Yokoo, M. (2000). Complex dynamics in a cobweb model with adaptive production adjustment. Journal of Economic Behavior $\& 3$ Organization, 41(2), 101-115.

Orazem, P. and Miranowski, J. (1986). An indirect test for the specification of expectation regimes. The Review of Economics and Statistics, 68(4), 603-609.

Orden, D. and Fackler, P. L. (1989). Identifying monetary impacts on agricultural prices in VAR models. American Journal of Agricultural Economics, 71(2), 495-502.

Osborne, T. (2004). Market news in commodity price theory: Application to the Ethiopian grain market. The Review of Economic Studies, 71(1), 133-164.

Park, A. (2006). Risk and household grain management in developing countries. Economic Journal, 
116(514), 1088-1115.

Pashigian, B. P. (1987). Cobweb theorem. In J. Eatwell, M. Milgate and P. Newman (eds.) The New Palgrave: A Dictionary of Economics, (pp. 463-464). Basingstoke: Palgrave Macmillan, first edition.

Persson, K. G. (1996). The seven lean years, elasticity traps, and intervention in grain markets in pre-industrial Europe. The Economic History Review, 49(4), 692-714.

Persson, K. G. (1999). Grain Markets in Europe, 1500-1900: Integration and Deregulation. Cambridge: Cambridge University Press.

Peterson, H. H. and Tomek, W. G. (2005). How much of commodity price behavior can a rational expectations storage model explain? Agricultural Economics, 33(3), 289-303.

Prescott, E. C. (1977). Should control theory be used for economic stabilization? Carnegie-Rochester Conference Series on Public Policy, 7, 13-38.

Rebelo, S. (2005). Real business cycle models: Past, present and future. The Scandinavian Journal of Economics, 107(2), 217-238.

Robertson, J. C. and Orden, D. (1990). Monetary impacts on prices in the short and long run: Some evidence from New Zealand. American Journal of Agricultural Economics, 72(1), 160-171.

Rosen, S., Murphy, K. M. and Scheinkman, J. A. (1994). Cattle cycles. The Journal of Political Economy, 102(3), 468-492.

Sadoulet, E. and de Janvry, A. (1995). Quantitative Development Policy Analysis. Baltimore: Johns Hopkins University Press.

Samuelson, P. A. (1957). Intertemporal price equilibrium: A prologue to the theory of speculation. Weltwirtschaftliches Archiv, 79, 181-219.

Sarris, A. H. (2000). Has world cereal market instability increased? Food Policy, 25(3), 337-350.

Scheinkman, J. A. and Schechtman, J. (1983). A simple competitive model with production and storage. The Review of Economic Studies, 50(3), 427-441.

Shively, G. (1996). Food price variability and economic reform: An ARCH approach for Ghana. American Journal of Agricultural Economics, 78(1), 126-136.

Sims, C. A. (2006). Rational inattention: Beyond the linear-quadratic case. The American Economic Review, 96(2), 158-163.

Slayton, T. (2009). Rice Crisis Forensics: How Asian Governments Carelessly Set the World Rice Market on Fire. Working Paper 163, Center for Global Development.

Srinivasan, P. V. and Jha, S. (2001). Liberalized trade and domestic price stability. The case of rice and wheat in India. Journal of Development Economics, 65(2), 417-441.

Stokey, N. L. and Lucas, R. E., Jr. (1989). Recursive Methods in Economic Dynamics. Cambridge: Harvard University Press.

Takayama, T. and Judge, G. G. (1971). Spatial and temporal price allocation models. Amsterdam: 


\section{North-Holland.}

Timmer, C. P. (2010). Reflections on food crises past. Food Policy, 35(1), 1-11.

Turnovsky, S. J. (1974). Price expectations and the welfare gains from price stabilization. American Journal of Agricultural Economics, 56(4), 706-716.

Turnovsky, S. J. (1976). The distribution of welfare gains from price stabilization: The case of multiplicative disturbances. International Economic Review, 17(1), 133-148.

Turnovsky, S. J., Shalit, H. and Schmitz, A. (1980). Consumer's surplus, price instability, and consumer welfare. Econometrica, 48(1), 135-152.

Tyers, R. and Anderson, K. (1992). Disarray in World Food Markets: A Quantitative Assessment. Cambridge: Cambridge University Press.

Voituriez, T. (2001). What explains price volatility changes in commodity markets? Answers from the world palm-oil market. Agricultural Economics, 25(2-3), 295-301.

Walter, J. and Wrightson, K. (1976). Dearth and the social order in early modern England. Past and Present, 71(1), 22-42.

Waugh, F. V. (1944). Does the consumer benefit from price instability? The Quarterly Journal of Economics, 58(4), 602-614.

Waugh, F. V. (1964). Cobweb models. Journal of Farm Economics, 46(4), 732-750.

Westerhoff, F. and Reitz, S. (2005). Commodity price dynamics and the nonlinear market impact of technical traders: empirical evidence for the US corn market. Physica A: Statistical Mechanics and its Applications, 349(3-4), 641-648.

Williams, J. C. and Wright, B. D. (1991). Storage and Commodity Markets. New York: Cambridge University Press.

Woodford, M. (2009). Convergence in macroeconomics: Elements of the new synthesis. American Economic Journal: Macroeconomics, 1(1), 267-279.

Working, H. (1949). The theory of price of storage. The American Economic Review, 39(6), 12541262 .

Wright, B. D. (1979). The effects of ideal production stabilization: A welfare analysis under rational behavior. The Journal of Political Economy, 87(5), 1011-1033.

Wright, B. D. (1993). Dynamic perspectives on agricultural policy issues. American Journal of Agricultural Economics, 75(5), 1113-1125.

Wright, B. D. (2001). Storage and price stabilization. In B. L. Gardner and G. C. Rausser (eds.) Marketing, Distribution and Consumers, volume 1B, part 2 of Handbook of Agricultural Economics, chapter 14, (pp. 817-861). Amsterdam: Elsevier.

Wright, B. D. (2012). International grain reserves and other instruments to address volatility in grain markets. World Bank Research Observer, 27(2), 222-260.

Wright, B. D. and Williams, J. C. (1982a). The economic role of commodity storage. The Economic 
Journal, 92(367), 596-614.

Wright, B. D. and Williams, J. C. (1982b). The roles of public and private storage in managing oil import disruptions. The Bell Journal of Economics, 13(2), 341-353.

Wright, B. D. and Williams, J. C. (1988a). The incidence of market-stabilising price support schemes. The Economic Journal, 98(393), 1183-1198.

Wright, B. D. and Williams, J. C. (1988b). Measurement of consumer gains from market stabilization. American Journal of Agricultural Economics, 70(3), 616-627.

Yang, S.-R. and Brorsen, B. W. (1992). Nonlinear dynamics of daily cash prices. American Journal of Agricultural Economics, 74(3), 706-715.

Zeldes, S. P. (1989). Optimal consumption with stochastic income: Deviations from certainty equivalence. The Quarterly Journal of Economics, 104(2), 275-298.

Zhang, W.-B. (2006). Discrete Dynamical Systems, Bifurcations and Chaos in Economics, volume 204 of Mathematics in Science and Engineering. Series Editor: C.K. Chui. Amsterdam: Elsevier. 